\title{
PRESSURIZED FLUIDIZED-BED HYDRORETORTING \\ OF EASTERN OIL SHALES
}

Progress Report for the Period September 1992 - November 1992

By

M. J. Roberts

M. C. Mensinger

D. M. Rue

F. S. Lau

December 1992

Work Performed Under Contract No.: DE-AC21-87MC11089

For

U. S. Department of Energy Office of Fossil Energy Morgantown Energy Technology Center P.O. Box 880

Morgantown, West Virginia 26505

\section{MASTER}

By

Institute of Gas Technology

IIT Center, 3424 South State Street Chicago, Illinois 60616

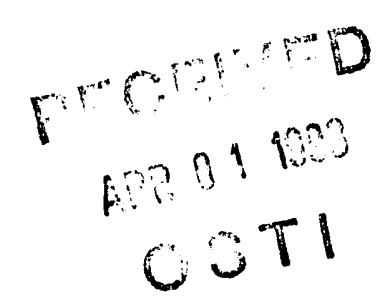




\section{DISCLAIMER}

This report was prepared as an account of work sponsored by an agency of the United States Government. Neither the United States Government nor any agency thereof, nor any of their employees, makes any warranty, express or implied, or assumes any legal liability or responsibility for the accuracy, completeness, or usefulness of any information, apparatus, product, or process disclosed, or represents that its use would not infringe privately owned rights. Reference herein to any specific commercial product, process, or service by trade name, trademark, manufacturer, or otherwise does not necessarily constitute or imply its endorsement, recommendation, or favoring by the United States Government or any agency thereof. The views and opinions of authors expressed herein do not necessarily state or reflect those of the United States Government or any agency thereof. 


\section{EXECUTIVE SUMMARY}

This report presents the work performed during the program quarter from September 1, 1992 through November 30, 1992, under U.S. Department of Energy (DOE) Contract No. DE-AC21-87MC11089 for the profect "Pressurized FluidizedBed Hydroretorting (PFH) of Eastern Oil Shales." The Institute of Gas Technology (IGT) is the prime contractor for the program extension to develop the PFH II system technology. Four institutions are working with IGT as subcontractors; their responsibilities and achievements in the program are discussed below in the appropriate tasks.

Some of the tasks in the original program were not continued in the current program extension. The task achievements discussed below represent the active tasks of the program.

In Subtask 3.7 (Innovative Reactor Concept Testing), IGT conducted methane cracking tests with mixtures of spent shale (25 weight percent) and inert material ( 75 weight percent) at temperatures, pressures, and residence times in the ranges of $1700^{\circ}$ to $1950^{\circ} \mathrm{F}, 50$ to $1000 \mathrm{psig}$, and 10 to 20 minutes, respectively. Preliminary results confirmed that the extent of methane cracking increases with increasing temperature and decreases with increasing pressure. Next month, the cracking tests will be completed and a draft final report will be prepared.

In Subtask 3.9 (Catalytic Hydroretorting), IGT conducted catalytic hydroretorting tests using both regenerable and throw-away catalysts. The tests were conducted in an existing laboratory-scale reactor at $925^{\circ} \mathrm{F}$ and 1000 psig with a 20-minute residence time to ensure a common basis for comparing the oil yields and properties to those of baseline (no catalyst) tests. Preliminary results showed that the catalysts tested improved the quality of the oil produced. The commercial Co-Mo catalyst removed more sulfur and nitrogen from the oil than the Ni-Mo catalyst. Detailed results of the tests conducted in this subtask will be presented in the final report.

In Subtask 3.10 (Autocatalysis in Hydroretorting), the University of Alabama (UA) identified four metals as potential catalysts for shale hydroretorting and conducted autocatalysis tests with two of the metals. The tests were conducted with dry beneficiated Alabama shale. Next month, UA will conduct tests with the other two metals and prepare the draft final report for this subtask.

In Subtask 3.11 (Shale 011 Upgrading and Evaluation), IGT conducted ofl upgrading tests with both conventional and novel catalysts. The catalysts used in the tests included two commercially available oll hydrotreating catalysts and one catalyst prepared at IGT. Preliminary results of the tests conducted with these catalysts show that the oil quality was improved. The nickel-containing catalyst reduced the specific gravity of the ofl from 0.996 to $0.895 \mathrm{~g} / \mathrm{mL}$ and decreased the sulfur and nitrogen contents by 89 and 72 percent, respectively.

A test conducted using methane as feed showed no improvement in the oil specific gravity and small decreases in the oil nitrogen and sulfur contents. 
Signiflcant coking was observed. Another catalyst was used in the next test and steam was added to reduce coking. Coking again occurred and only minimal improvements in the oil properties were achieved. Next month, the oil upgrading tests will be completed and draft final report for this subtask will be prepared.

The University of Alabama Mineral Resources Institute (MRI) is responsible for the work being conducted in Task 4 (Beneficiation Research).

In Subtask 4.1.3 (Stirred Ball Mill Grinding), MRI installed a larger capacity agitation unit on the Denver flotation cell to ensure that the required rotation could be achieved when working with the continuous mill. Also, a larger motor was installed on the 1.6-liter polyurethane-lined mill for continuous runs. After the equipment modifications were made, MRI completed the planned stirred ball milling tests with shale having a $d_{90}$ of 40 micrometers $(\mu \mathrm{m})$ at 55 percent solids and began preparation of the draft final report for this subtask.

In Subtask 4.1 .5 (Alternative Technology Evaluation), MRI completed a reduced scope of work on this subtask and is preparing a draft final report based on the results.

In Subtask 4.1.6 (Ultrafine Size Separation), MRI found that some data from hydrocyclone tests conducted previously were biased due to excessive heating of the slurry by the $1 \frac{1}{2}$-inch centrifugal pump. In subsequent tests, MRI found that temperature significantly affected the size distribution of the solids in the hydrocyclone overflow stream. Increasing the slurry temperature from $7^{\circ}$ to $42^{\circ} \mathrm{C}$ increased the $-12 \mu \mathrm{m}$ fraction in the cyclone overflow from 56.1 to 66.8 weight percent. Over the same temperature range, the $+24 \mu \mathrm{m}$ fraction decreased from 19.6 to 10.2 weight percent. The effect is likely due to decreased viscosity of the slurty due to increased temperature.

MRI also conducted studies in the rod mill with the secondary cyclone underflow product to determine the time required to reduce this product to -24 $\mu \mathrm{m}$. The secondary cyclone underflow was ground to $-24 \mu \mathrm{m}$ and mixed with the combined cyclone overflow to yield a flotation feed product for the column cell. MRI conducted column flotation tests to confirm the viability of a twostage flotation circuit. Rougher flotation testing was completed but cleaner and scavenger flotation tests will extend into next month. MRI also began analyzing the data collected previously for inclusion in the draft final report for this task.

In Subtask 4.2.1 (Column Flotation Tests), MRI conducted a test to determine the residence time distribution of solid particles in the deep froth flotation column. Preliminary results show that the solids residence time in the column was about 7 minutes; that of the liquid was about 12.8 minutes. The experimental work for this subtask has been completed and MRI will prepare the draft final report next month.

In Subtask 4.4 (Integrated Grinding and Flotation), the University of Kentucky Center for Applied Energy Research (UK-CAER) conducted tests in the SYMUSEP separator in which air was added directly into the grinding section 
rather than using a sparger for bubble generation. With an air flow rate of 3 L/min, a yield of 76 percent was achieved; however, the concentrate grade was only 25.1 percent carbon. UK-CAER also conducted tests using the SYMUSEP separator as a grinding/ rougher flotation stage followed by the Ken-Flote column as a scavenger flotation stage. The froth produced in the rougher flotation stage contained 26 to 30 percent carbon with a 44 to 46 percent recovery. The recovery in the scavenger stage was 75 to 85 percent with concentrate grades of 17 to 20 percent carbon. Combining the froth produced by the rougher and scavenger stages gave an overall recovery of 96 percent with a concentrate grade of 24 percent carbon.

Filtration tests were conducted with beneficiated shale slurry to determine the effects of cake thickness and pressure. At the optimum conditions (cake thickness of $0.5 \mathrm{~cm}$, pressure of $40 \mathrm{psig}$, and a 2 -minute filtration time), the filter cake produced contained 40 weight percent moisture. Complete results will be summarized in the draft flnal report.

In Subtask 4.7 (Economic Analysis), MRI determined the cost of concentrate production by amortizing the capital investment over a 25-year period at various interest rates. At current conditions, the capital cost of concentrates could be lower than the $\$ 34.95 /$ ton that was estimated by Johnson and Riley (Roberts and Schaefer Company). ${ }^{1}$ MRI will prepare the draft final report on this subtask next month.

In Subtask 6.2.2 (Wastewater Treatability), Tennessee Technological University (TTU) continued attempts to acclimate microorganisms to stripped PFH wastewater during the quarter. To date no evidence of microbial acclimation has been observed. Also, no growth has been observed in tests to determine if microorganisms would use 4-methyl pyridine as a sole nitrogen source. Treatability tests on combinations of phenol, methyl ethyl ketone, and aniline continued during the quarter. The chemical oxygen demand measured in these tests has been reduced to low levels within about 94 hours. Complete results will be presented in the draft final report for this subtask.

In Subtask 6.2.3 (Waste Management Facility Conceptual Design), TTU evaluated water quality criteria for cooling water and evaluated import water quality at potential plant sites. The complete results of TTU's work on this subtask will be presented in the draft final report.

In Task 8 (Project Management and Reporting), IGT continued to review and monitor the progress of the subcontractors via telephone and written reports. In October, DOE notified IGT that funds were not available to fully fund work on the project and requested a revised statement of work to reduce the research effort to correspond to the amount of money available. IGT prepared a revised statement of work and a cost proposal for the revised statement of work with input from its subcontractors. A meeting was held with DOE at IGT in November to discuss the reduction in program work scope.

Task 9 (Information Required for the National Environmental Policy Act) was inactive pending DOE approval of the NEPA document submitted previously. 
TABLE OF CONTENTS

Page

INTRODUCTION

1

ACHIEVEMENTS

Task 3. Testing of Process Improvement Concepts

Task 4. Beneficiation Research

Task 6. Environmental Data and Mitigation Analyses

Task 8. Project Management and Reporting

Task 9. Information Required for the National E'nvironmental Policy Act

FUTURE PLANS

ACKNOWLEDGMENTS 
Figure No.

6-1 Change in COD, Phenol, MEK, Aniline and 4-Methyl Pyridine Concentrations With Time During 4-Way Combination Experiment

6-2 Change in Phenol, MEK, Aniline and 4-Methyl Pyridine Concentrations With Time During 4-Way Combination Experiment

6-3 Change in 4-Methyl Pyridine Concentration with Time Due to Air Stripping at an Air Flow Rate of About $257 \mathrm{~mL} / \mathrm{min} / \mathrm{L}$

6-4 Change in COD, Phenol, and MEK Concentrations With Time During Combination Experiment With Phenol and MEK (Data Were Corrected For Air Stripping of MEK)

6-5 Change in COD, Phenol, and Aniline Concentration With Time During Combination Experiment With Phenol and Aniline

\section{LIST OF TABLES}

Table No.

6-1 Parameters That Influence Scale Formation 18

6-2 Sources of Fouling Deposits 19

6-3 Import Water Sources Investigated 20

6-4 Characteristics of Import Water Sources 21

6-5 Boiler Feedwater Quality Criteria 22 


\section{INTRODUCTION}

The Devonian oil shales of the Eastern United States are a significant domestic energy resource. The overall objective of the multi-year program, initiated in October 1987 by the U.S. Department of Energy (Contract No. DEAC21-87MC11089), is to perform the research necessary to develop the pressurized fluidized-bed hydroretorting ( $P F H$ ) process for producing oil from Eastern oil shales. The program also incorporates research on technologies in areas such as raw shale preparation, beneficiation, product separation and upgrading, and waste disposal that have the potential of improving the economics and/or environmental acceptability of recovering oll from oil shales using the PFH process. The program is divided into the following active" tasks:

- Task 3. Testing of Process Improvement Concepts

- Task 4. Beneficiation Research

- Task 6. Environmental Data and Mitigation Analyses

- Task 8. Project Management and Reporting

- Task 9. Information Required for the National

Environmental Policy Act

In order to accomplish all of the program objectives, the Institute of Gas Technology (IGT), the prime contractor, is working with four other institutions: The University of Alabama/Mineral Resources Institute (MRI), the University of Alabama College of Engineering (UA), University of Kentucky Center for Applied Energy Research (UK-CAER), and Tennessee Technological University (TTU).

This report presents the work performed during the program quarter from September 1, 1992 through November 30, 1992.

* Some of the tasks in the original program were not continued in the current program extension. The task achievements discussed below represent the active tasks of the program. 


\section{ACHIEVEMENTS}

\section{Task 3. Testing of Process Improvement Concepts}

The objective of this task is to obtain data on novel process concepts that have the potential to improve the economics for $P F H$ processing of beneficiated Eastern shales. This task is divided into four active subtasks that correspond to the novel concepts being tested: 3.7. Innovative PFH Reactor Concept Testing (Methane Cracking and Cracking-Combustion Tests), 3.9. Catalytic Hydroretorting, 3.10. Autocatalys is in Hydroretorting, and 3.11. Shale Oil Upgrading and Evaluation. Subtask 3.10 is being conducted by the University of Alabama College of Engineering (UA).

\section{Subtask 3.7. Innovative Reactor Concept Testing}

The objective of this subtask is to demonstrate the technical feasibility of generating hydrogen by cracking by-product methane gas and combusting the carbon produced by the cracking reactions. Work is divided into two subtasks: 3.7.1. PFB Methane Cracking and 3.7.2. PFBC of Carbon From Cracking.

\section{Subtask 3.7.1. PFB Methane Cracking}

The objective of this subtask is to determine operating conditions needed to crack the hydrocarbon gases from the PFH process to generate hydrogen and carbon by conducting laboratory-scale tests. An existing laboratory-scale reactor will be modified to include continuous gas flow through a batch fluidized bed. On-line gas detectors will be used to collect data during the cracking and combustion tests.

\section{Discussion}

During the quarter, all of the equipment required for the cracking apparatus was received. The external thermocouples and the differential pressure gauge/controller were installed and assembly of the reactor was completed. Instrumentation for the equipment was checked and found to be operational. The unit was pressure tested and the mixture of combusted shale ( 25 weight percent) and silica sand ( 75 weight percent) to be used as a bed material was prepared.

The first two cracking tests were conducted at $1775^{\circ}$ and $1950^{\circ} \mathrm{F}$ at a pressure of 200 psig. Although fluidization was maintained throughout the heat-up and steady-state periods, the silica sand fused in both tests. Gas samples were taken during the tests and the product gas and bed material were submitted for analyses.

In the next series of tests, the silica sand was replaced with alumina beads $(-40+60$ mesh) to eliminate fusing of the bed material at high temperatures. Five successful tests were conducted in the cracking reactor at temperatures of $1700^{\circ}$ to $1950^{\circ} \mathrm{F}$ and pressures of 50 to $1000 \mathrm{psig}$. Steady-state periods ranging from 10 to 20 minutes were used for the tests because carbon 
deposited from the cracking reaction bullt up quickly in the reactor. The tests were completed successfilly and no solids sintering was experienced.

Preliminary results confirm that the extent of methane cracking increases with increasing temperature and decreases with increasing pressure. Detailed results of the cracking tests will be presented when the chemical analyses are complete.

Next quarter, IGT will complete tests in the range of cracking conditions of interest and determine the effects of shale/alumina ratio on the cracking reaction. The draft final report for this subtask will be prepared.

\section{Subtask 3:7.2. PFBC of Carbon From Cracking}

The objectives of this subtask are to demonstrate the removal of deposited carbon from the surface of the spent beneficlated shale by combustion and to evaluate shale for cracking effectiveness and particle stability through multiple cycles of cracking and combustion. The apparatus being built for tests in Subtask 3.7 .1 will also be used for these tests.

\section{Discussion}

This subtask was originally scheduled to be inftiated in December 1992. Due to the reduction in program work scope, it will not be initiated.

\section{Subtask 3.9. Catalytic Hydroretorting}

The objective of this subtask is to improve the quality of PFH-produced shale oil in-situ by utilizing catalysts. Tests will be conducted in a small laboratory-scale hydroretorting unit using hydrotreating catalysts. These catalysts will be used in the retort 1 tself and will be of two types, regenerable and throw-away.

\section{Discussion}

IGT conducted six catalytic hydroretorting tests during the quarter using throw-away catalysts. Catalyst loadings were $1000 \mathrm{ppm}$ (weight basis) for the first five tests and 10,000 ppm for the sixth test. Catalysts were selected from the list of potential catalysts identified previously. The effects of the catalysts on oil yield and quality will be summarized in the draft final report on this subtask.

The catalyzed-shale tests were conducted in an existing laboratory-scale reactor. Test conditions of $925^{\circ} \mathrm{F}$ and $1000 \mathrm{psig}$ with a 20 -minute residence time were used in these tests to ensure a common basis for comparing the oil yields and properties to those of tests with no catalyst present. Five replicate baseline tests with noncatalyzed beneficiated shale were conducted previously to provide a statistically valid bench mark for comparing the effects of various catalysts. The oil yleld from the baseline tests averaged 58.6 gallons per ton (standard deviation of 0.35 gallon per ton). The specific gravity and carbon-to-hydrogen ratio of the oil were $1.004 \mathrm{~g} / \mathrm{mI}$ and 8.97, respectively. 
Also during the quarter, seven catalytic hydroretorting tests were conducted with regenerable catalysts. In the first three tests, 25 grams of catalyst were placed in the reactor exit 1 ine, and 100 grams of shale were charged to the batch PFH reactor. Reactor conditfons and flows were such that the exit line was heated to about $800^{\circ} \mathrm{F}$. At this temperature, the oil would pass through the catalyst as a vapor. The catalysts placed in the exit line included nickel-molybdenum and cobalt-molybdenum commercial catalysts and a caralyst developed at IGT.

Preliminary results of these tests showed that all three catalysts improved the product oil quality. The commercial catalysts performed better than the catalyst produced by IGT. The commercial Co-Mo catalyst removed more sulfur and nitrogen from the oil than the Ni-Mo catalyst.

The fourth test was conducted in bed using the commercial Co-Mo catalyst. In this test, 25 grams of catalyst was ground to -20 mesh and mixed with 100 grams of shale by hand. This allowed simultaneous introduction of catalyst and shale to the batch PFH retort. The liquids and gases produced during the test were collected. Preliminary results show that the catalyst produced some decreases in the sulfur and nitrogen contents of the oil, but the effects were not as great as when the catalyst was placed in the exit gas line.

The other three batch PFH tests were conducted under similar conditions with a commercial $\mathrm{Ni}$-Mo catalyst, a tungsten-promoted $\mathrm{Ni}$-Mo catalyst, and a Co-Mo catalyst. Detailed results of the tests conducted in this subtask will be presented in the draft final report.

\section{Subtask 3.10. Autocatalysis in Hydroretorting}

The objective of this subtask is to investigate the effects of potentially catalytic minerals or alkali metal oxides naturally present in shale on hydroretorting characteristics and product yields. Tests will be conducted in an existing laboratory-scale batch reactor using as-received shale and shale impregnated with potentially catalytic metals.

\section{Discussion}

During the quarter in preparation for autocatalytic hydroretorting tests, UA dried a $4-\mathrm{kg}$ batch of beneficiated Alabama shale at $80^{\circ} \mathrm{C}$ in an argon atmosphere. The moisture content of the as-received sample was about $44 . \mathrm{J}$ weight percent. About 500 grams of the resulting dry cake were crushed in a glove box purged with nitrogen; about 100 grams were crushed in air to determine the effects of atmospheric oxidation on subsequent autocatalysis tests. Both samples were analyzed for carbon and hydrogen content in a LECO analyzer. The results indicate that there was no appreclable oxidation of shale due to the presence of atmospheric oxygen duxing crushing.

Becalse $C_{6}$ to $C_{14}$ hydrocarbons will likely be present in the oil produced during autocatalysis tests, UA prepared a mixture of some typical paraffinic and aromatic compounds to calibrate the chromatograph. The flow rate of hydrogen into the reactor was cali. rated at about 0.5 standard liters per minute. 
Also during the quarter, UA identified four metals as potential catalysts for shale hydroretorting. Autocatalysis tests were conducted with two of the metals. Next quarter, UA will conduct tests with the other two metals concurrent with preparation of the draft final report for this subtask.

\section{Subtask 3.11. Shale Oil Upgrading and Evaluation}

The objective of this subtask is to investigate conventional and novel methods for upgrading the oil produced by shale hydroretorting. This subtask is divided into two subtasks: 3.11.1. Conventional Upgrading, and 3.11.2. Novel Approach to Upgrading.

\section{Subtask 3:11.1. Conventional Upgrading}

The objective of this subtask is to evaluate conventional hydrotreating technology for upgrading shale oil produced from the PFH process to transportation fuel.

\section{Discussion}

During the quarter. IGT conducted oil upgrading tests with conventional catalysts. The catalysts used in the tests included two commercially available oil hydrotreating catalysts and one catalyst prepared at IGT. The hydrogen upgrading tests were conducted at a pressure of $2000 \mathrm{psig}$ and a temperature of $750^{\circ} \mathrm{F}$.

One of the commercial catalysts contains nickel; the other cobalt. Preliminary results of the tests conducted with these catalysts show that the ofl quality was improved; however the Ni-containing catalyst was more effective. The raw shale oil had a specific gravity of $0.996 \mathrm{~g} / \mathrm{mL}$ and contained 2.75 weight percent sulfur and 1.44 weight percent nitrogen. The Ni-containing catalyst reduced the specific gravity to $0.895 \mathrm{~g} / \mathrm{mL}$ and decreased the sulfur and nitrogen contents by 89 and 72 percent, respectively. The Co-containing catalyst reduced the specific gravity to $0.920 \mathrm{~g} / \mathrm{mL}$ and decreased the sulfur and nitrogen contents by 84 and 57 percent, respectively.

\section{Subtask 3.11.2. Novel Upgrading}

The objective of this subtask is to determine if the whole product oil can be hydrotreated in a novel one-step catalytic process without the use of hydrogen or severe operating conditions.

\section{Discussion}

During the quarter, IGT conducted five ofl upgrading tests, including four tests that were operationally successiul. The first test was not successful because product oil could not be consistently discharged from the oil collection system. The oil collection system was retubed after the first test to correct the problem.

The four successful oil upgrading tests included three tests in hydrogen and one test in methane. The catalysts used in the tests included two comer- 
cially available oll hydrotreating catalysts and one catalyst prepared at IGT. The hydrogen upgrading tests were conducted at a pressure of $2000 \mathrm{psig}$ and a temperature of $750^{\circ} \mathrm{F}$. The fourth successful test was conducted with an IGTprepared catalyst with methane at a fressure of $1000 \mathrm{psig}$ and a temperature of $750^{\circ} \mathrm{F}$. Steady-state periods of two to four hours were achleved for each of the tests.

One of the commercial catalysts contains nickel; the other cobalt. Preliminary results of the tests conducted with these catalysts show that the oil quality was improved; however the $\mathrm{Ni}$-containing catalyst was more effective. The raw shale o1l had a specific gravity of $0.996 \mathrm{~g} / \mathrm{mL}$ and contained 2.75 weight percent sulfur and 1.44 weight: percent nitrogen. The Ni-containing catalyst decreased the specilic gravity to $0.895 \mathrm{~g} / \mathrm{mL}$ and decreased the sulfur and nit:ogen contents by 89 and 72 percent, respectively. The Co-containing catalyst decreased the specific gravlty to $0.920 \mathrm{~g} / \mathrm{mL}$ and decreased the sulfur and nitrogen contents by 84 and 57 percent, respectively.

Three tests were also conducted this quarter with catalysts prepared at IGT specifically for use in a methane atmosphere. The first test was performed using methane alone as the feed gas. In the other two tests, steam was added to help reduce coking during upgrading. The three tests were conducted at $750^{\circ} \mathrm{F}$ and a pressure of 1000 psig.

The first test in methane showed no improvement in the oil specific gravity and only small decreases in the ofl nitrogen and sulfur contents. Significant coking was observed. A different catalyst was used for the second test and steam was added to reduce coking. Coking again occurred and only minimal improvements in the oil properties were achieved.

The third test was a replicate of the second test because of poor pressure control in the second test. The product yields of the replicate test were similar to that of its predecessor.

IGT also conducted seven tests with a commercial Ni-Mo catalyst and a W-promoted Ni-Mo catalyst. The goal of the tests was primarily to upgrade the light shale oil fraction, boiling below $650^{\circ} \mathrm{F}$. The first two tests were made in a hydrogen atmosphere at $2000 \mathrm{psig}$ with the $\mathrm{Ni}$-Mo and W-promoted catalysts at $750^{\circ} \mathrm{F}$. The third test was conducted in a hydrogen atmosphere at $2000 \mathrm{psig}$ with the W-prowoted Ni-Mo catalyst at $700^{\circ} \mathrm{F}$.

Four other upgrading tests were performed in a methane atmosphere at $1000 \mathrm{psig}$. Two tests were conducted with the Ni-Mo catalyst at $750^{\circ}$ and $800^{\circ} \mathrm{F}$. Some coke formation occurred during the test at $750^{\circ} \mathrm{F}$. However, in the test conducted at $800^{\circ} \mathrm{F}$, coke formation was so extensive that the reactor plugged and the test had to be terminated. The last two tests were replicate tests in methane at $750^{\circ} \mathrm{F}$ using a catalyst developed at IGT. No coke was observed on the catalyst a ter these tests.

Next quarter, oll upgrading tests will be completed and will continue to focus on the shale oil fraction boiling below $650^{\circ} \mathrm{F}$. The oil upgrading characteristics of several IGT-developed catalysts will be evaluated in methane for resistance to coking. The final report for this subtask will be prepared. 
Task 4. Beneficiation Research

The objective of this task is to test several novel and advanced grinding and beneficiation concepts for processing Eastern oil shales. The ultimate goal is to develop a minimum-cost system for delivering shale concentrates of suitable form to the PFH process. The University of Alabama Mineral Resources Institute (MRI) has primary responsibility for this program task.

The active work in this task is divided into four subtasks: 4.1. Grinding Studies, 4.2.1. Column Flotation Tests, 4.4. Integrated Grinding and Flotation, and 4.7. Economic Analysis. Subtask 4.4 is being conducted by the University of Kentucky. Center for Appiled Energy Research (UK-CAER).

\section{Subtask 4.1. Grinding Studies}

This subtask is divided into three subtasks: 4.1.3. Stirred Ball Mill Grinding, 4.1.5. Alternative Technology Evaluation, and 4.1.6. Ultrafine Size Separation.

\section{Subtask 4.1.3. Stirred Ball Mill Grinding}

During the quarter, MRI obtained and installed a larger capacity ( $/$ HP) agitation unit for the Denver flotation cell so that the required rotation could be achieved when working with the continuous mill. The original agitation unit did not have sufficient power ( $/ \mathrm{HP}$ ) to maintain the required rpm under load.

Also, a larger motor (1/ HP) was installed on the small-scale polyurethane lined mill ( $1.6-\mathrm{L}$ capacity) for continuous runs. Efforts are also underway to connect the motor with a data acquisition system for power measurements. A sample of shale having a $d_{90}$ of 40 micrometers $(\mu \mathrm{m})$ at 55 percent solids was prepared for the grinding runs.

Once these modifications were made, MRI completed the planned stirred ball milling tests and began preparation of the draft final report for this subtask.

\section{Subtask 4.1.5. Alternative Technology Evaluation}

The objective of Subtask 4.1 .5 is to evaluate several alternative comminution technologies to determine which could replace conventional technologies in the oil shale beneficiation scheme.

MRI completed a reduced scope of work on this subtask and is preparing a draft final report based on the results.

\section{Subtask 4.1.6. Ultrafine Size Separation}

MRI found that some data included in the quarterly report for June August 1992 for hydrocyclone tests conducted with the 14.3-mm vortex finder were biased due to excessive heating of the slurry by the 1 h-inch centrifugal pump. In control tests conducted subsequently, MRI found that slurry tempera- 
ture significantly affected the size distribution of the solids in the overflow stream from the hydrocyclone. Increasing the slurry temperature from $7^{\circ}$ to $42^{\circ} \mathrm{C}$ increased the $-12 \mu \mathrm{m}$ fraction in the cyclone overflow from 56.1 to 66.8 weight percent. Over the same temperature range, the $+24 \mu \mathrm{m}$ fraction decreased from 19.6 to 10.2 weight percent. The effect is likely due to decreased viscosity of the slurry due to increased temperature.

MRI conducted batch tests with a smaller centrifugal pump ( 1 inch) and the $14.3-\mathrm{mm}$ vortex finder. The results showed that the apex spigot of $9.4 \mathrm{~mm}$ (rather than $6.4 \mathrm{~mm}$ ) and a cyclone feed pressure of $15 \mathrm{psig}$ (rather than 10 psig) would be required to yield the desired results. Even though a smaller pump was employed in this series of tests, the slurry temperature increased from $23^{\circ}$ to $32^{\circ} \mathrm{C}$ within about 20 minutes.

Based on the results of the second batch test series, the bulk sample of -150 -mesh slurry was hydrocycloned continuously at a pressure of $25 \mathrm{psig}$. The results showed that 39.7 percent of the feed solids reported to the overflow stream; the $d_{90}$ was $21.5 \mu \mathrm{m}$.

MRI also conducted studies in the rod mill with the secondary cyclone underflow product to determine the time required to reduce this product to -24 $\mu \mathrm{m}$. The secondary cyclone underflow was ground to $-24 \mu \mathrm{m}$ and mixed with the combined cyclone overflow to yield a flotation feed product for the column cell.

MRI conducted column flotation tests to confirm the viability of a twostage flotation circuit. Rougher flotation has been completed but cleaner and scavenger flotatinn tests will extend into next quarter. MRI also began analyzing the data collected previously for inclusion in the draft final report for this task.

\section{Subtask 4.2.1. Column Flotation Tests}

This subtask is divided into two subtasks: 4.2.1.1. Column Flotation Modeling, and 4.2.1.2. Circuit Evaluation - Indiana Shale.

The primary objective of Subtask 4.2.1.1 is to develop a steady-state phenomenological model of column froth flotation for ultrafine ground shale, which relates the behavior of various classes of particles to column operating parameters. Another objective is to develop an on-line procedure for measuring the oil content of a shale sample on the basis of $x$-ray back-scattering intensity. The objectives of Subtask 4.2.1.2 are to test the applicability of grinding circuits developed for Alabama shale to Indiana shale and to modify the circuits for the specific grinding and kerogen liberation characteristics of Indiana shale.

\section{Discussion}

MRI conducted one test to determine the residence time distribution of solid particles in the deep froth flotation column. The operating parameters were an air flow rate of 4.5 standard liters per minute, slurry feed rate of $250 \mathrm{~mL} / \mathrm{min}$, and a tailings rate of $250 \mathrm{~mL} / \mathrm{min}$. Dowfroth 250 was added at 60 
ppm. Fifteen grams of silica sand $(-37 \mu \mathrm{m})$ were injected into the column at time zero. Slurry samples were taken at specific time intervals during the next 30 minutes. The preliminary results show that the solids residence time in the column was about 7 minutes; that of the liquid was about 12.8 minutes.

MRI has completed the experimental work for this subtask and will prepare the draft final report next month.

\section{Subtask 4.4. Integrated Grinding and Flotation}

The objective of this subtask is to continue the development of the integrated grinding and flotation SYMUSEP process and to investigate methods for dewatering the resultant kerogen/water slurry. Subtask 4.4 is divided into three subtasks: 4.4.1. Acquisition and Characterization of Samples, 4.4.2. SYMUSEP Separator Testing, 4.4.3. Pilot Plant Studies, and 4.4.4. Dewatering Studies.

\section{Discussion}

Column Flotation Studies: The SYMUSEP separator built at UK-CAER did not perform satisfactorily when initially tested. Therefore, UK-CAER obtained the original SYMUSEP separator from B. Datta Research and installed it in the laboratory. In the initial tests with the original SYMUSEP separator, air was added directly into the grinding section for fine bubble generation rather than using a sparger for bubble generation. The results indicated that using an air flow rate of $3 \mathrm{~L} / \mathrm{min}$ in the SYMUSEP separator provided a yield of 76 percent. However, the concentrate contained only 25.1 percent carbon.

UK-CAER also conducted tests using the SYMUSEP separator as a grinding/ rougher flotation stage followed by the Ken-Flote column as a scavenger flotation stage to recover carbon from the tallings stream produced by the SYMUSEP separator. At grinding speeds of 200 to $340 \mathrm{rpm}$, the froth produced in the rougher flotation stage contained 26 to 30 percent carbon with a recovery of 44 to 46 percent. The recovery in the scavenger stage was 75 to 85 percent with concentrate grades of 17 to 20 percent carbon. Combining the froth produced by the rougher and scavenger stages gave an overall recovery of 96 percent with a concentrate grade of 24 percent carbon.

UK-CAER conducted an analysis on a sample of finely ground ( 90 percent $-10 \mu \mathrm{m})$ oil shale to determine the grade-recovery relationship and define the limits of both recovery and grade using froth flotation. The analysis showed that if a concentrate grade of 30 percent carbon is desired, the maximum recovery that could be achieved with flotation at this grind would be 75 percent. For a concentrate grade of 40 percent carbon, the maximum recovery decreases to 45 percent. Results close to the limits defined by the release analysis were obtained using the SMUSEP separator as a rougher flotation stage followed by the Ken-Flote column as a scavenger flotation stage and combining both froth products.

Dewatering Studies: UK-CAER conducted basic surface characterization of the kerogen concentrate obtained in the pilot-scale flotation tests. The concentrate showed a point-of-zaro charge (PZC) at a $\mathrm{pH}$ of 3.0 . The PZC is a 
value above which particles are negatively charged and below which they are positively charged. In the presence of $10^{-4} \mathrm{M} / \mathrm{L}(50 \mathrm{ppw}) \mathrm{Cu}^{+2}$ lons, the PZC occurred at $\mathrm{pH}$ of 3,5 , and 10.5. These data indicate that with copper ions, there are $3 \mathrm{pH}$ values at which there will be zero charge on particles and dewatering of the concentrate will be relatively easy. In the presence of $10^{-4}$ $\mathrm{M} / \mathrm{L}$ of $\mathrm{Al}^{+3}$ ions, the $\mathrm{PZC}$ occurred at $\mathrm{pH} 4.5$ and 9.0 .

Pressure filtration tests were conducted with the kerogen slurry to determine the effect of cake chickness. Cake molsture decreased from 44 to 40 percent as the cake thickness was increased from 0.25 to $0.7 \mathrm{~cm}$. As filtration time was varied from 1 to 5 minutes, cake molsture remained constant at 40 percent. Using the optimum conditions determined from these tests (2 minutes filtration time and $0.5-\mathrm{cm}$ cake thickness), pressure was varied from 10 to 60 psig; moisture decreased from 75 to 37.4 percent. The optimum pressure was determined to be $40 \mathrm{psig}$, which gave filter cake containing 40 percent moisture. These dewatering results vary considerably from those reported previously and can be attributed, in part, to a reduction in the $\mathrm{pH}$ of the slurry from 6.5 to 3.0 due to oxidation during storage.

UK-CAER continued tests to determine the effects of an anionic surfactant (sodium 2-ethylhexyl sulfate) on pressure filtration. At a surfactant dose of $1 \mathrm{~kg} / t o n$, the moisture content of the cake was reduced from 43 to 39 percent. Increasing the surfactant dose above this level did not further reduce the moisture content. The $\mathrm{pH}$ of the oil shale concentrate did not have any significant effect on cake moisture since the solid particulates are negatively charged from $\mathrm{pH} 3$ to 11 and electrostatic repulsive forces prevent increased surfactant adsorption.

A few tests were also conducted in which an electirc field was applied during pressure filtration. UK-CAER found that an electric field ( 120 volts, $1 \mathrm{amp}$ ) applied across the filter cake during pressure filtration reduced the cake moisture to as low as 36 percent. Increasing the current to 3 amps further reduced the moisture to 34.5 percent. Cakes with moisture contents as low as 25 percent have been obtained with this approach. UK-CAER will summarize these results in the final report.

\section{Subtask 4.7. Economic Analysis}

The objective of this subtask is to update the estimate of the cost of beneficiating Alabama shale to reflect the effects of current technological development.

\section{Discussion}

During the quarter, MRI corrected some of the capital cost figures that were presented in the quarterly report for June - August 1992. The corrected capital cost is 6.3 percent higher than that estimated in 1988 by Johnson and Riley (Roberts and Schaefer Company). 1 The operating cost estimate increased by only 0.2 percent, because costs that increased were offset by a decrease in the cost of power purchased locally. 
Also, MRI combinel the capital and operating costs to show the cost of concentrates delivered to the hydroretorting operation. The capital cost of concentrate was obtained by calculating the cost of amortizing the capital investment over a 25-year period at various assumed rates of interest. The Roberts and Schaefer report assumed an interest rate of 15 percent. However, current economic conditions (ie., prime rate at 6 percent) make it realistic to assume lower rates for the cost of capital. The cost of delivered concentrates was, therefore, calculated at 15, 12, 10 and 8 percent interest. At current conditions, the cost of concentrates could be lower than the $\$ 34.95 /$ ton estimated by Johnson and Riley.'

MRI continued to review the Roberts and Schaefer report to establish equipment substitutions that could be made in estimating the effect of technology advances on the cost of oll shale beneficlation. MRI will prepare the draft final report on this subtask next month.

\section{Task 6. Environmental Data and Mitigation Analyses}

The overall objective of this task is to obtain environmental data relating to PFH and to shale beneficiation and to analyze the potential environmental impact of the integrated PFH process. This task consists of four subtasks: 6.2.2. Wastewater Treatability, 6.2.3. Waste Management Facility Conceptual Design, 6.4.1 PFH Process Analyses, and 6.4.4. Economics. Subtasks 6.2 .2 and 6.2 .3 are being conducted by the Tennessee Technological University (TTU).

\section{Subtask 6.2. Water Availability and Treatment Studies}

\section{Subtask 6.2.2. Wastewater Treatability}

The objective of this subtask is to determine suitable techniques for treating wastewater generated during shale processing.

\section{Discussion}

TTU continued attempts to acclimate microorganisms to the stripped PFH waste water during the quarter. Shaker flasks with 5,10 , and 25 percent (by volume) of the stripped $P F H$ waste were maintained and evaluated for microbial growth. Acclimation as evidenced by substantial drops in the chemical oxygen demand (COD) in the shaker flasks was not observed.

TTU also conducted tests to determine if microorganisms would use 4-methyl pyridine as a nitrogen source. A shaker flask was prepared with 250 $\mathrm{mg} / \mathrm{L}$ of phenol and $50 \mathrm{mg} / \mathrm{L}$ of 4 -methyl pyridine along with other essential nutrients. A biological seed was taken from a combination of activated sludge from the local sewage treatment plant, cow and horse manure, and soil. No growth has been observed to date.

TIU conducted a treatability study on a combination synthetic waste with phenol and MEK at an initial concentration of about $250 \mathrm{mg} / \mathrm{L}$, and aniline and 4-methyl pyridine at about $300 \mathrm{mg} / \mathrm{L}$. The COD decreased from an initial total value of 1937 to $63 \mathrm{mg} / \mathrm{L}$ after about 94 hours. This COD reduction was associ- 
ated with a simultaneous reduction in the concentration of the organic compounds. The concentration of the 4-methyl pyridine was greater than the residual concentration of COD after 94 hours. This would be expected since this compound is only partially oxidized during the COD test. Figure 6-1 shows the change in $C O D$ and the concentration of the organic compounds during the experiment.

The MEK concentration decreased to less than $1 \mathrm{mg} / \mathrm{L}$ after about 43 hours. Once the MEK was depleted, the rate of removal of phenol and aniline increased. Their concentrations decreased to less than $1 \mathrm{mg} / \mathrm{L}$ after about 94 hours. The change in the concentration of these compounds with respect to time is shown in Figure 6-2. The data presented in the figures were corrected for the air stripping of MEK.

The concentration of 4-methyl pyridine decreased about 46 percent during 109 hours. This reduction could have been the result of biodegradation or bioadsorption. The data in Figure 6-3 shows that the reduction in 4-methyl pridine concentration was not the result of air stripping. Further tests will be required to determine the mechanism responsible for this reduction.

Two compatibility studies were performed. The first was with phenol and MEK in combination at initial concentrations of about $250 \mathrm{mg} / \mathrm{L}$. The results of this experiment (Figure $6-4$ ) show that the COD was reduced from an initial concentration of 1043 to $19 \mathrm{mg} / \mathrm{L}$ in about 37 hours. During this same period, the MEK and phenol concentrations were reduced from an initial 222 and 254 $\mathrm{mg} / \mathrm{L}$, respectively, to less than $1 \mathrm{mg} / \mathrm{L}$ each.

The second compatibility study was with phenol and aniline at concentrations of about 250 and $300 \mathrm{mg} / \mathrm{L}$, respectively. The results (Figure 6-5) show that the COD was reduced from an initial 1269 to about $80 \mathrm{mg} / \mathrm{L}$ after 89 hours. Phenol decreased from an initial concentration of 248 to less than $1 \mathrm{mg} / \mathrm{L}$ in about 42 hours. Aniline was reduced from an initial concentration of 297 to less than $1 \mathrm{mg} / \mathrm{L}$ in about 89 hours.

The data in Figures $6-4$ and $6-5$ suggest that under the conditions of the experiment MEK will be preferentially biodegraded before phenol and that phenol will be biodegraded before aniline. More research is needed to confirm these results.

\section{Subtask 6.2.3. Waste Management Facility Conceptual Design}

The objective of this subtask is to design a conceptual wastewater and process water treatment facility for a commercial-scale PFH plant.

\section{Discussion}

Cooling Water Quality Criteria: About 7.55 MGD of makeup water are required for the open recirculating cooling system of the combined PFH plant 


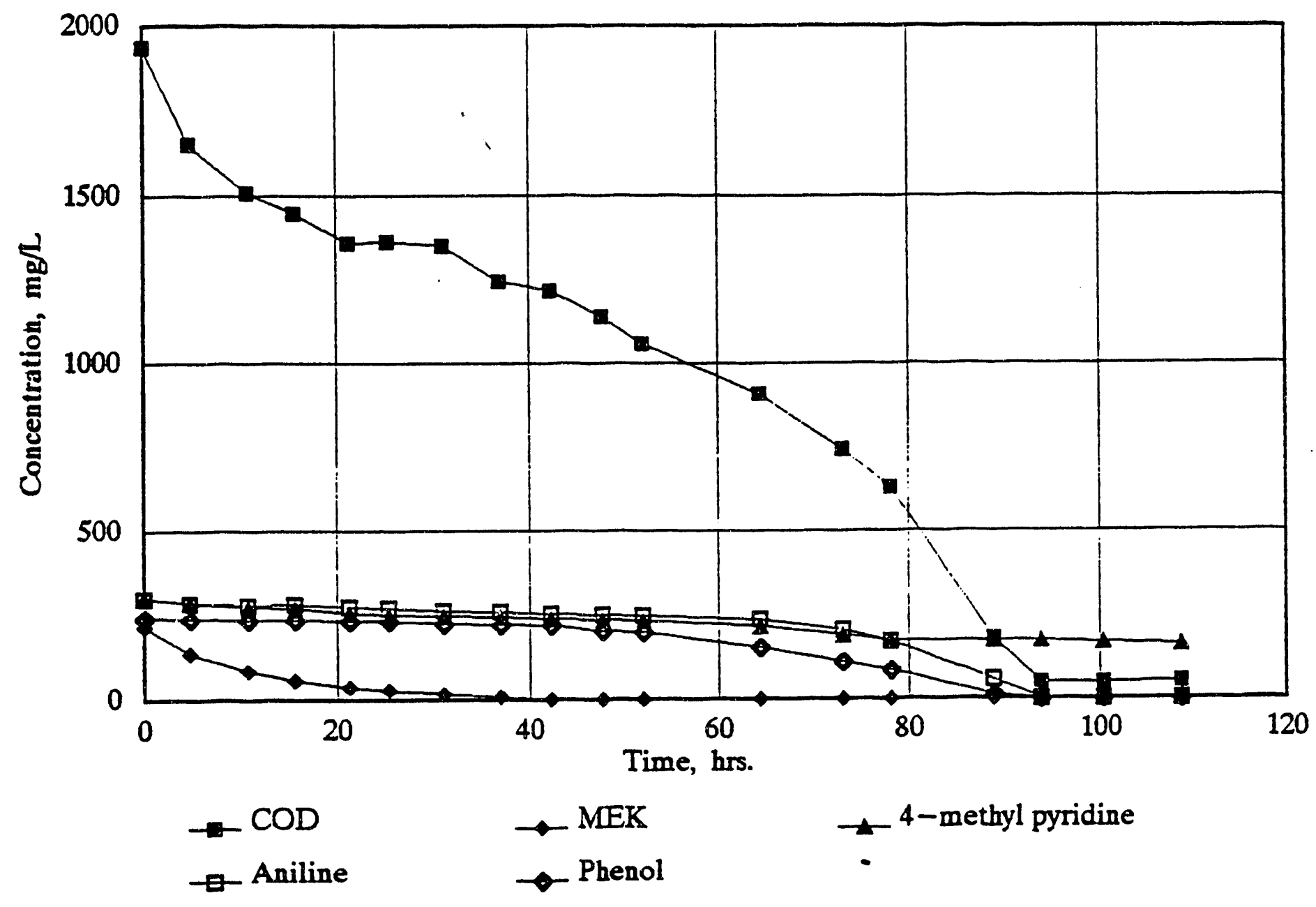

Figure 6-1. CHANGE IN COD, PHENOL, MEK, ANILINE AND 4-METHYL PYRIDINE CONCENTRATIONS WITH TIME DURING 4-WAY COMBINATION EXPERIMENT 


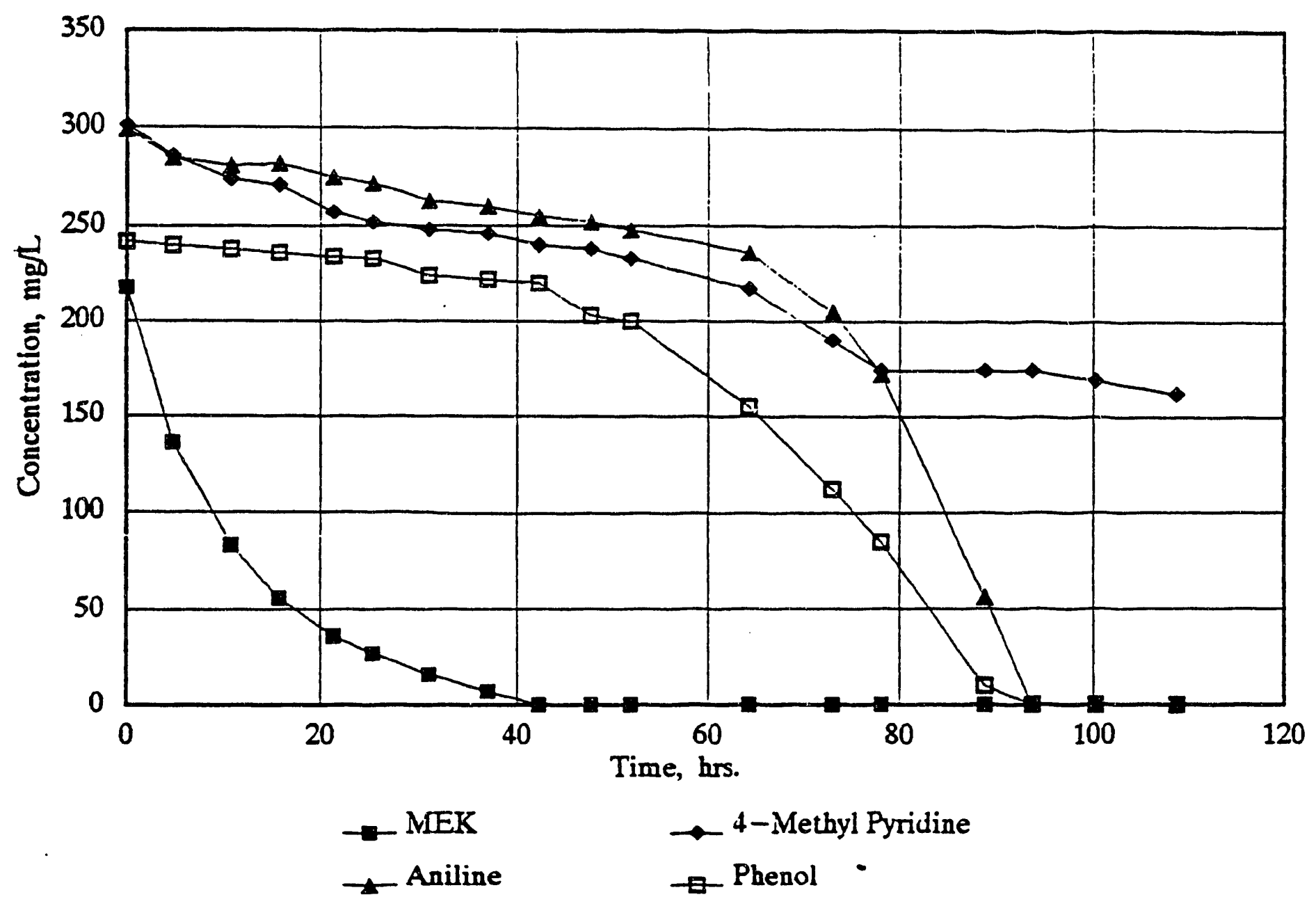

Figure 6-2. CHANGE IN PHENOL, MEK, ANILINE AND 4-METHYL PYRIDINE CONCENTRATIONS WITH TIME DURING 4-WAY COMBINATION EXPERIMENT 


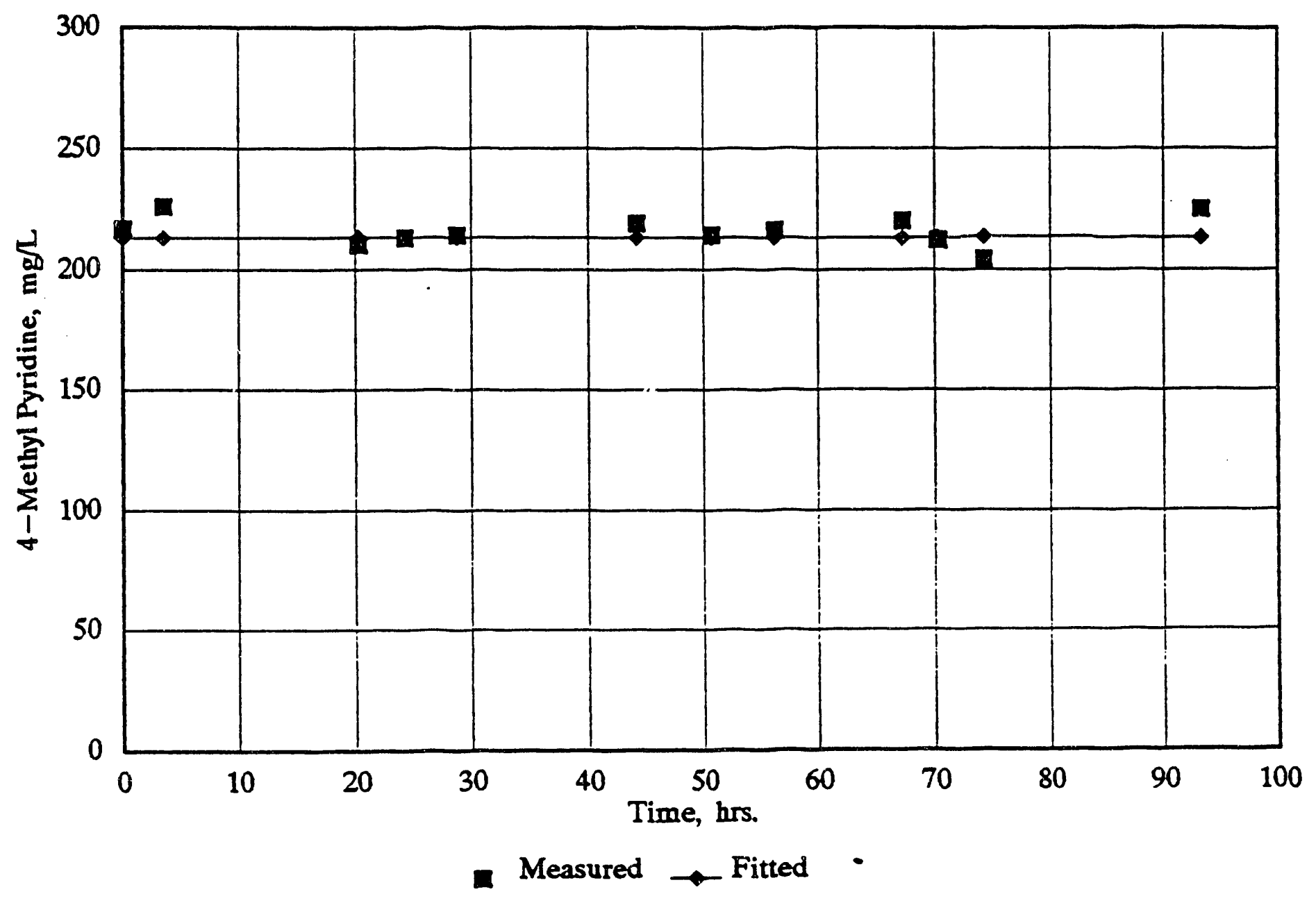

Figure 6-3. CHANGE IN 4-METHYL PYRIDINE CONCENTRATION WITH TIME DUE TO AIR STRIPPING AT AN AIR FLOW RATE OF ABOUT $257 \mathrm{~mL} / \mathrm{min} / \mathrm{L}$ 


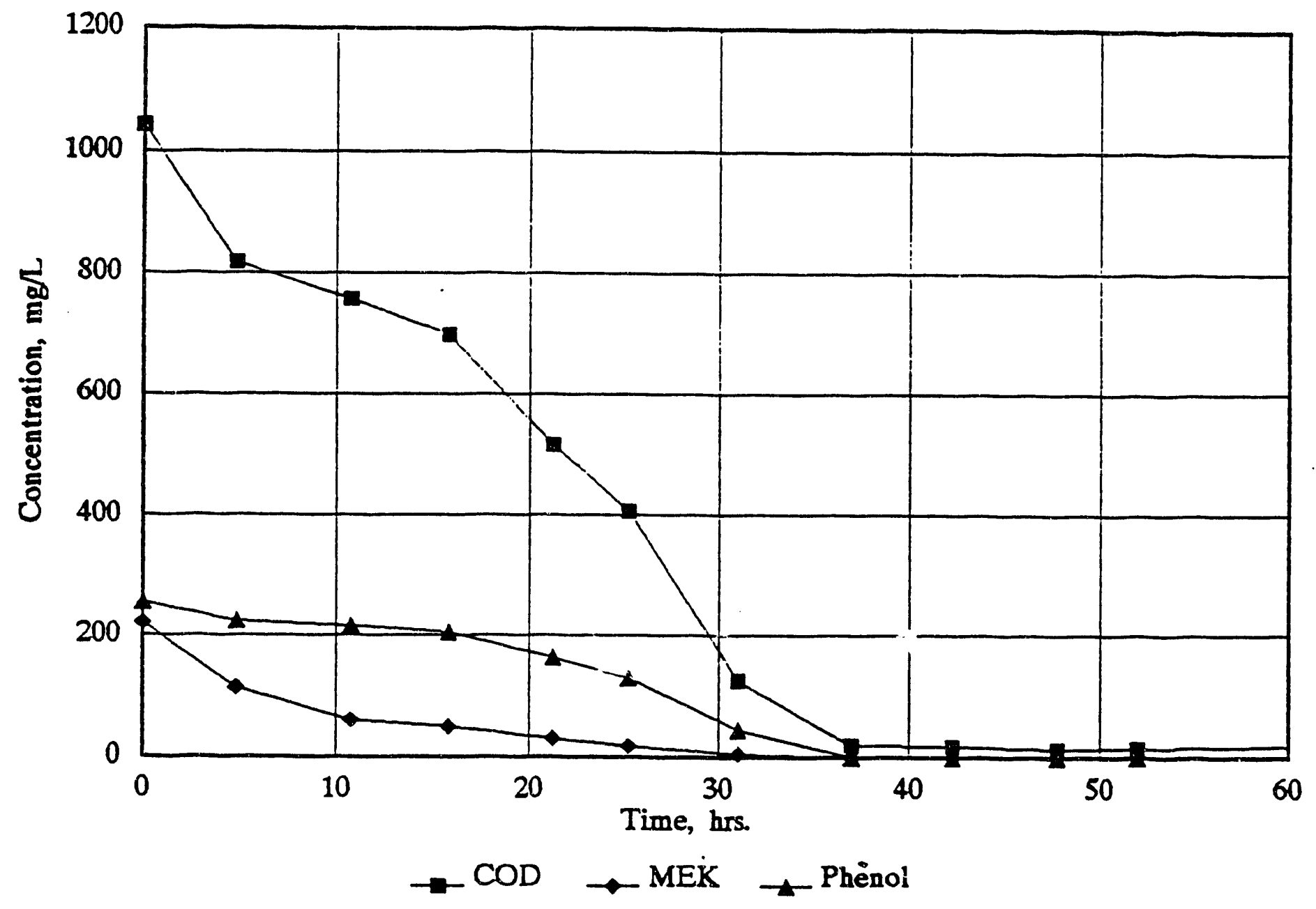

Figure 6-4. CHANGE IN COD, PHENOL, AND MEK CONCENTRATIONS WITH TIME DURING COMBINATION EXPERIMENT WITH PHENOL AND MEK (Data were corrected for air stripping of MEK) 


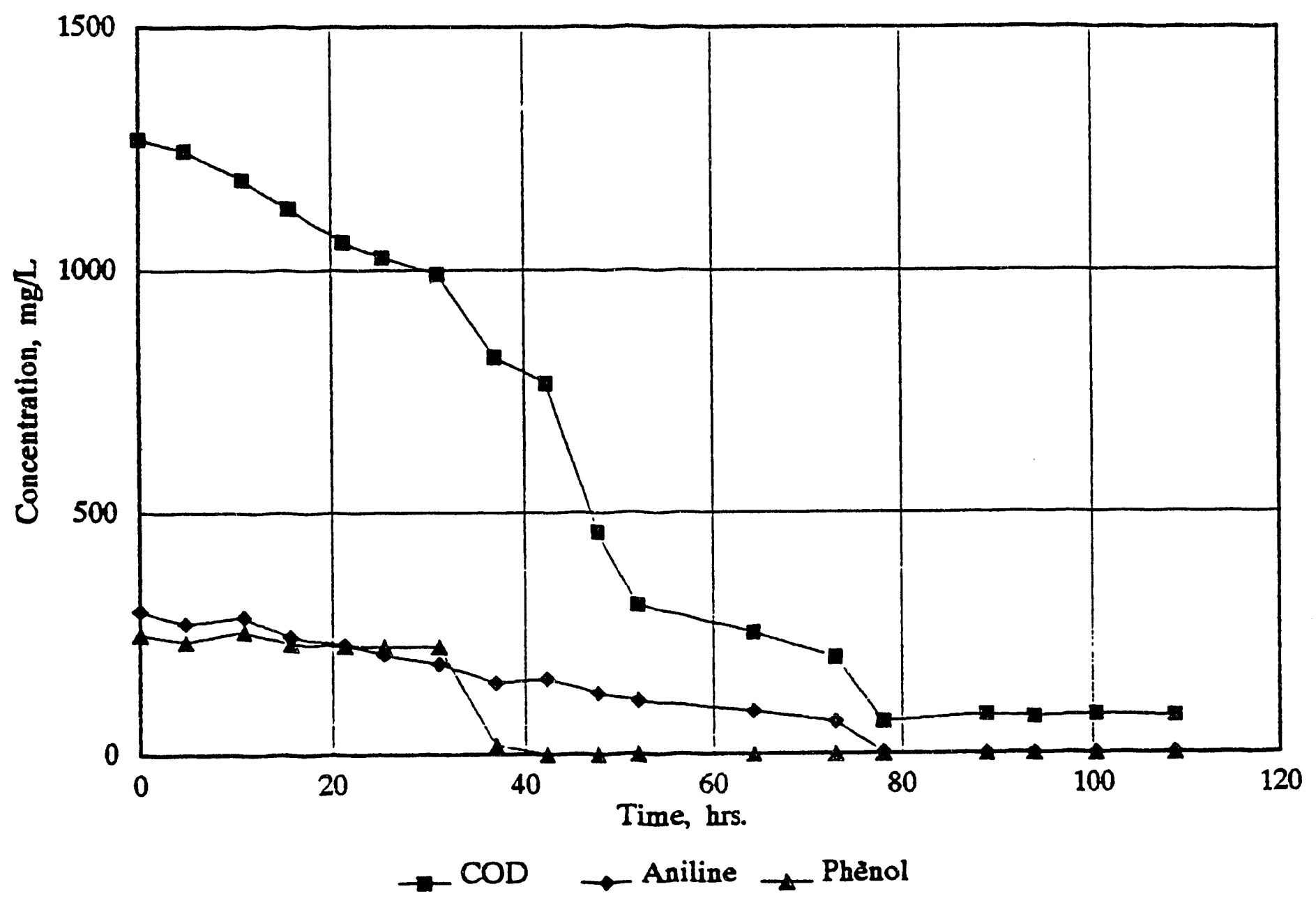

Figure 6-5. CHANGE IN COD, PHENOL, AND ANILINE CONCENTRATION WITH TIME DURING COMBINATION EXPERIMENT WITH PHENOL AND ANILINE 
and steam power plant. This makeup cooling water should be of such quality as to avoid the three major water-related cooling water system problems corrosion, scale, and fouling. A brief description of each is given below.

For an open recirculating system that requires substantial makeup water, corrosion presents a serious problem. Oxygen presents the most serious threat. At elevated temperatures and at points of high heat transfer, oxygen can cause severe pitting corrosion. In addition to pitting corrosion, galvanic corrosion can occur due to high concentrations of total dissolved solid;. Corrosion may also occur due to alkall attack.

Scale formation presents a significant problem for cooling water systems with high makeup flow rates. Scale forms from the precipitation of compounds that become insoluble at higher temperatures, such as calcium carbonate. Additional scale-related problems are associated with the presence of ions such as $\mathrm{Ca}$ and magnesium, which can combine with avallable phosphate, silica, sulphate, and carbonate to form hard heat-transfer-limiting scale. In general, for open recirculating systems, the $\mathrm{Ca}$ and $\mathrm{Mg}$ hardness should be low enough so that a cooling tower can operate with the circulating water equal to at least several concentrations of makeup before scale forms at a significant rate. Table 6-1 lists some of the important variables that must be controlled to prevent significant scale formation.

\section{Table $6-1$. PARAMETERS THAT INFLUENCE SCALE FORMATION ${ }^{2}$}

$$
\begin{aligned}
& \frac{\text { Variable }}{\mathrm{Ca}, \mathrm{Mg}} \\
& \mathrm{M}, \mathrm{PH}, \mathrm{T} \\
& \mathrm{SO}_{4}, \mathrm{SiO}_{2}
\end{aligned}
$$

\section{Effects}

Define scaling tendency of water.

Define concentrations of carbonate and bicarbonate, and solubility of $\mathrm{CaCO}_{3}$.

Must be controlled to prevent sulfate and silicate scales.

$\mathrm{Ca}$ and $\mathrm{Mg}$ hardness define the scaling tendency of the water. Total alkalinity (M), $\mathrm{pH}$, and temperature (T) define the concentrations of carbonate and bicarbonate ions in the water, and also the solubility of $\mathrm{CaCO}_{3}$. All of these must be controlled within acceptable ranges to ensure scale-free operation. Concentrations of sulfate and silica must also be controlled to prevent formation of gypsum and silica scale.

Fouling has the same effect on cooling water systems as scaling, but fouling also promotes severe corrosion under the deposits. Fouling results from the settling out of suspended solids, build up of corrosion products, and growth of microbial masses. Table 6-2 shows some sources of foulants in a typical recirculating system.

Fouling problems are complicated by microbial activity. Slime deposits on tubes not only interfere with efficient heat transfer, but also act as a trap to enmesh suspended solids, further impeding heat transfer. In addition, by-products of bacterial metabolism influence water chemistry, including the tendency for scale to form or metal to corrode. 
Table 6-2. SOURCES OF FOULING DEPOSITS ${ }^{2}$

\begin{tabular}{|c|c|c|}
\hline Raw Water & Airborne & Recirculating Water \\
\hline $\begin{array}{l}\text { Colloidal organics } \\
\text { organics }\end{array}$ & Dirt & $\begin{array}{l}\text { Scale: } \mathrm{CaCO}_{3}, \mathrm{CaSO}_{4} \text {, } \\
\mathrm{MgSiO}_{3}\end{array}$ \\
\hline Silt, dirt & $\begin{array}{l}\text { Reactive gases } \\
\mathrm{H}_{2} \mathrm{~S}, \mathrm{SO}_{2}, \mathrm{NH}_{3}\end{array}$ & $\begin{array}{l}\text { Corrosion product: } \\
\mathrm{Fe}_{2} \mathrm{O}_{3}\end{array}$ \\
\hline Soluble iron & & $\begin{array}{l}\text { Process leaks - } \\
\text { hydrocarbons, sulfides }\end{array}$ \\
\hline $\begin{array}{l}\text { Microbial } \\
\text { contamination }\end{array}$ & $\begin{array}{l}\text { Microbial } \\
\text { contamination }\end{array}$ & Microbial deposits \\
\hline
\end{tabular}

Corrosion, scale, and fouling rarely occur independently of one another. Usually two or three develop together to cause loss of heat transfer and premature metal loss. Therefore, special care must be taken to avoid corrosion, scale, and fouling causing contaminants.

Makeup water control programs for cooling systems vary considerably because each installation presents different environmental factors and operating problems. A common method used within industry for the determination of the scaling tendency and corrosiveness of a water is the use of two calculable indexes - the Langelier and Ryznar. Both indexes make use of chemical equilibrium principles.

The Langelif: Index makes use of the fact that each natural water supply is completely stable with respect to $\mathrm{CaCO}_{3}$ solubility at a certain $\mathrm{pH}\left(\mathrm{pH}_{3}\right)$. The $\mathrm{pH}_{3}$ can be calculated from water quality data, including calcium content, total alkalinity, temperature and total dissolved solids. Once the $\mathrm{pH}_{3}$ of the water is determined, it can be compared with the actual $\mathrm{pH}$ of the water. The Langelier Index is calculated from $\left(\mathrm{pH}-\mathrm{pH}_{\mathrm{s}}\right)$. If the result is positive, the water is a scaling water - it is over saturated with respect to $\mathrm{CaCO}_{3}$. If the result is negative, the water is under saturated with respect to $\mathrm{CaCO}_{3}$ and will attack the metal of the system in the presence of oxygen in an attempt to obtain equilibrium. Therefore, the water in this condition is corrosive and the more negative the number the more corrosive the water. ${ }^{3}$

The Ryznar Index is a modification of the Langelier Index. Its intent is to reliably predict the likelihood of scale formation and corrosion in flowing systems. The Ryznar Index is calculated from (2 $\left.\mathrm{pH}_{\mathrm{z}}-\mathrm{pH}\right)$. Ryznar Index numbers of about 7 indicate that the water is quite stable, neither corrosive nor scaling. The water becomes progressively more scale forming as the index drops below 6 and becomes progressively more corrosive as the index increases above 7.4

Due to the extreme temperature changes that occur within cooling systems, scale and corrosion control by the Langelier and Ryznar Indexes alone rarely offer a satisfactory solution. This is because the $\mathrm{pH}_{3}$ is temperature dependent. The next step taken is chemical treatment of the water, 2,4 which 


\section{PRESSURIZED FLUIDIZED-BED HYDRORETORTING \\ OF EASTERN OIL SHALES}

Progress Report for the Period September 1992 - November 1992

By

M. J. Roberts

M. C. Mensinger

D. M. Rue

F. S. Lau

December 1992

Work Performed Under Contract No.: DE-AC21-87MC11089

For

U. S. Department of Energy Office of Fossil Energy Morgantown Energy Technology Center P.O. Box 880

Morgantown, West Virginia 26505

\section{MASTER}

By

Institute of Gas Technology

IIT Center, 3424 South State Street Chicago, Illinois 60616

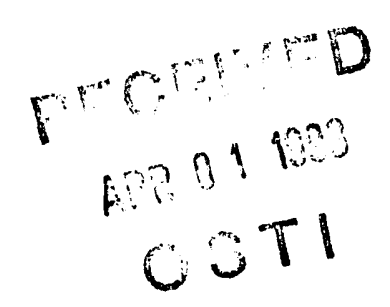




\section{DISCLAIMER}

This report was prepared as an account of work sponsored by an agency of the United States Government. Neither the United States Government nor any agency thereof, nor any of their employees, makes any warranty, express or implied, or assumes any legal liability or responsibility for the accuracy, completeness, or usefulness of any information, apparatus, product, or process disclosed, or represents that its use would not infringe privately owned rights. Reference herein to any specific commercial product, process, or service by trade name, trademark, manufacturer, or otherwise does not necessarily constitute or imply its endorsement, recommendation, or favoring by the United States Government or any agency thereof. The views and opinions of authors expressed herein do not necessarily state or reflect those of the United States Government or any agency thereof. 


\section{EXECUTIVE SUMMARY}

This report presents the work performed during the program quarter from September 1, 1992 through November 30, 1992, under U.S. Department of Energy (DOE) Contract No. DE-AC21-87MC11089 for the profect "Pressurized FluidizedBed Hydroretorting (PFH) of Eastern Oil Shales." The Institute of Gas Technology (IGT) is the prime contractor for the program extension to develop the PFH II system technology. Four institutions are working with IGT as subcontractors; their responsibilities and achievements in the program are discussed below in the appropriate tasks.

Some of the tasks in the original program were not continued in the current program extension. The task achievements discussed below represent the active tasks of the program.

In Subtask 3.7 (Innovative Reactor Concept Testing), IGT conducted methane cracking tests with mixtures of spent shale (25 weight percent) and inert material ( 75 weight percent) at temperatures, pressures, and residence times in the ranges of $1700^{\circ}$ to $1950^{\circ} \mathrm{F}, 50$ to $1000 \mathrm{psig}$, and 10 to 20 minutes, respectively. Preliminary results confirmed that the extent of methane cracking increases with increasing temperature and decreases with increasing pressure. Next month, the cracking tests will be completed and a draft final report will be prepared.

In Subtask 3.9 (Catalytic Hydroretorting), IGT conducted catalytic hydroretorting tests using both regenerable and throw-away catalysts. The tests were conducted in an existing laboratory-scale reactor at $925^{\circ} \mathrm{F}$ and 1000 psig with a 20-minute residence time to ensure a common basis for comparing the oil yields and properties to those of baseline (no catalyst) tests. Preliminary results showed that the catalysts tested improved the quality of the oil produced. The commercial Co-Mo catalyst removed more sulfur and nitrogen from the oil than the Ni-Mo catalyst. Detailed results of the tests conducted in this subtask will be presented in the final report.

In Subtask 3.10 (Autocatalysis in Hydroretorting), the University of Alabama (UA) identified four metals as potential catalysts for shale hydroretorting and conducted autocatalysis tests with two of the metals. The tests were conducted with dry beneficiated Alabama shale. Next month, UA will conduct tests with the other two metals and prepare the draft final report for this subtask.

In Subtask 3.11 (Shale 011 Upgrading and Evaluation), IGT conducted ofl upgrading tests with both conventional and novel catalysts. The catalysts used in the tests included two commercially available oll hydrotreating catalysts and one catalyst prepared at IGT. Preliminary results of the tests conducted with these catalysts show that the oil quality was improved. The nickel-containing catalyst reduced the specific gravity of the ofl from 0.996 to $0.895 \mathrm{~g} / \mathrm{mL}$ and decreased the sulfur and nitrogen contents by 89 and 72 percent, respectively.

A test conducted using methane as feed showed no improvement in the oil specific gravity and small decreases in the oil nitrogen and sulfur contents. 
Signiflcant coking was observed. Another catalyst was used in the next test and steam was added to reduce coking. Coking again occurred and only minimal improvements in the oil properties were achieved. Next month, the oil upgrading tests will be completed and draft final report for this subtask will be prepared.

The University of Alabama Mineral Resources Institute (MRI) is responsible for the work being conducted in Task 4 (Beneficiation Research).

In Subtask 4.1.3 (Stirred Ball Mill Grinding), MRI installed a larger capacity agitation unit on the Denver flotation cell to ensure that the required rotation could be achieved when working with the continuous mill. Also, a larger motor was installed on the 1.6-liter polyurethane-lined mill for continuous runs. After the equipment modifications were made, MRI completed the planned stirred ball milling tests with shale having a $d_{90}$ of 40 micrometers $(\mu \mathrm{m})$ at 55 percent solids and began preparation of the draft final report for this subtask.

In Subtask 4.1 .5 (Alternative Technology Evaluation), MRI completed a reduced scope of work on this subtask and is preparing a draft final report based on the results.

In Subtask 4.1.6 (Ultrafine Size Separation), MRI found that some data from hydrocyclone tests conducted previously were biased due to excessive heating of the slurry by the $1 \frac{1}{2}$-inch centrifugal pump. In subsequent tests, MRI found that temperature significantly affected the size distribution of the solids in the hydrocyclone overflow stream. Increasing the slurry temperature from $7^{\circ}$ to $42^{\circ} \mathrm{C}$ increased the $-12 \mu \mathrm{m}$ fraction in the cyclone overflow from 56.1 to 66.8 weight percent. Over the same temperature range, the $+24 \mu \mathrm{m}$ fraction decreased from 19.6 to 10.2 weight percent. The effect is likely due to decreased viscosity of the slurty due to increased temperature.

MRI also conducted studies in the rod mill with the secondary cyclone underflow product to determine the time required to reduce this product to -24 $\mu \mathrm{m}$. The secondary cyclone underflow was ground to $-24 \mu \mathrm{m}$ and mixed with the combined cyclone overflow to yield a flotation feed product for the column cell. MRI conducted column flotation tests to confirm the viability of a twostage flotation circuit. Rougher flotation testing was completed but cleaner and scavenger flotation tests will extend into next month. MRI also began analyzing the data collected previously for inclusion in the draft final report for this task.

In Subtask 4.2.1 (Column Flotation Tests), MRI conducted a test to determine the residence time distribution of solid particles in the deep froth flotation column. Preliminary results show that the solids residence time in the column was about 7 minutes; that of the liquid was about 12.8 minutes. The experimental work for this subtask has been completed and MRI will prepare the draft final report next month.

In Subtask 4.4 (Integrated Grinding and Flotation), the University of Kentucky Center for Applied Energy Research (UK-CAER) conducted tests in the SYMUSEP separator in which air was added directly into the grinding section 
rather than using a sparger for bubble generation. With an air flow rate of 3 L/min, a yield of 76 percent was achieved; however, the concentrate grade was only 25.1 percent carbon. UK-CAER also conducted tests using the SYMUSEP separator as a grinding/ rougher flotation stage followed by the Ken-Flote column as a scavenger flotation stage. The froth produced in the rougher flotation stage contained 26 to 30 percent carbon with a 44 to 46 percent recovery. The recovery in the scavenger stage was 75 to 85 percent with concentrate grades of 17 to 20 percent carbon. Combining the froth produced by the rougher and scavenger stages gave an overall recovery of 96 percent with a concentrate grade of 24 percent carbon.

Filtration tests were conducted with beneficiated shale slurry to determine the effects of cake thickness and pressure. At the optimum conditions (cake thickness of $0.5 \mathrm{~cm}$, pressure of $40 \mathrm{psig}$, and a 2 -minute filtration time), the filter cake produced contained 40 weight percent moisture. Complete results will be summarized in the draft flnal report.

In Subtask 4.7 (Economic Analysis), MRI determined the cost of concentrate production by amortizing the capital investment over a 25-year period at various interest rates. At current conditions, the capital cost of concentrates could be lower than the $\$ 34.95 /$ ton that was estimated by Johnson and Riley (Roberts and Schaefer Company). ${ }^{1}$ MRI will prepare the draft final report on this subtask next month.

In Subtask 6.2.2 (Wastewater Treatability), Tennessee Technological University (TTU) continued attempts to acclimate microorganisms to stripped PFH wastewater during the quarter. To date no evidence of microbial acclimation has been observed. Also, no growth has been observed in tests to determine if microorganisms would use 4-methyl pyridine as a sole nitrogen source. Treatability tests on combinations of phenol, methyl ethyl ketone, and aniline continued during the quarter. The chemical oxygen demand measured in these tests has been reduced to low levels within about 94 hours. Complete results will be presented in the draft final report for this subtask.

In Subtask 6.2.3 (Waste Management Facility Conceptual Design), TTU evaluated water quality criteria for cooling water and evaluated import water quality at potential plant sites. The complete results of TTU's work on this subtask will be presented in the draft final report.

In Task 8 (Project Management and Reporting), IGT continued to review and monitor the progress of the subcontractors via telephone and written reports. In October, DOE notified IGT that funds were not available to fully fund work on the project and requested a revised statement of work to reduce the research effort to correspond to the amount of money available. IGT prepared a revised statement of work and a cost proposal for the revised statement of work with input from its subcontractors. A meeting was held with DOE at IGT in November to discuss the reduction in program work scope.

Task 9 (Information Required for the National Environmental Policy Act) was inactive pending DOE approval of the NEPA document submitted previously. 
TABLE OF CONTENTS

Page

INTRODUCTION

1

ACHIEVEMENTS

Task 3. Testing of Process Improvement Concepts

Task 4. Beneficiation Research

Task 6. Environmental Data and Mitigation Analyses

Task 8. Project Management and Reporting

Task 9. Information Required for the National E'nvironmental Policy Act

FUTURE PLANS

ACKNOWLEDGMENTS 
Figure No.

6-1 Change in COD, Phenol, MEK, Aniline and 4-Methyl Pyridine Concentrations With Time During 4-Way Combination Experiment

6-2 Change in Phenol, MEK, Aniline and 4-Methyl Pyridine Concentrations With Time During 4-Way Combination Experiment

6-3 Change in 4-Methyl Pyridine Concentration with Time Due to Air Stripping at an Air Flow Rate of About $257 \mathrm{~mL} / \mathrm{min} / \mathrm{L}$

6-4 Change in COD, Phenol, and MEK Concentrations With Time During Combination Experiment With Phenol and MEK (Data Were Corrected For Air Stripping of MEK)

6-5 Change in COD, Phenol, and Aniline Concentration With Time During Combination Experiment With Phenol and Aniline

\section{LIST OF TABLES}

Table No.

6-1 Parameters That Influence Scale Formation 18

6-2 Sources of Fouling Deposits 19

6-3 Import Water Sources Investigated 20

6-4 Characteristics of Import Water Sources 21

6-5 Boiler Feedwater Quality Criteria 22 


\section{INTRODUCTION}

The Devonian oil shales of the Eastern United States are a significant domestic energy resource. The overall objective of the multi-year program, initiated in October 1987 by the U.S. Department of Energy (Contract No. DEAC21-87MC11089), is to perform the research necessary to develop the pressurized fluidized-bed hydroretorting ( $P F H$ ) process for producing oil from Eastern oil shales. The program also incorporates research on technologies in areas such as raw shale preparation, beneficiation, product separation and upgrading, and waste disposal that have the potential of improving the economics and/or environmental acceptability of recovering oll from oil shales using the PFH process. The program is divided into the following active" tasks:

- Task 3. Testing of Process Improvement Concepts

- Task 4. Beneficiation Research

- Task 6. Environmental Data and Mitigation Analyses

- Task 8. Project Management and Reporting

- Task 9. Information Required for the National

Environmental Policy Act

In order to accomplish all of the program objectives, the Institute of Gas Technology (IGT), the prime contractor, is working with four other institutions: The University of Alabama/Mineral Resources Institute (MRI), the University of Alabama College of Engineering (UA), University of Kentucky Center for Applied Energy Research (UK-CAER), and Tennessee Technological University (TTU).

This report presents the work performed during the program quarter from September 1, 1992 through November 30, 1992.

* Some of the tasks in the original program were not continued in the current program extension. The task achievements discussed below represent the active tasks of the program. 


\section{ACHIEVEMENTS}

\section{Task 3. Testing of Process Improvement Concepts}

The objective of this task is to obtain data on novel process concepts that have the potential to improve the economics for $P F H$ processing of beneficiated Eastern shales. This task is divided into four active subtasks that correspond to the novel concepts being tested: 3.7. Innovative PFH Reactor Concept Testing (Methane Cracking and Cracking-Combustion Tests), 3.9. Catalytic Hydroretorting, 3.10. Autocatalys is in Hydroretorting, and 3.11. Shale Oil Upgrading and Evaluation. Subtask 3.10 is being conducted by the University of Alabama College of Engineering (UA).

\section{Subtask 3.7. Innovative Reactor Concept Testing}

The objective of this subtask is to demonstrate the technical feasibility of generating hydrogen by cracking by-product methane gas and combusting the carbon produced by the cracking reactions. Work is divided into two subtasks: 3.7.1. PFB Methane Cracking and 3.7.2. PFBC of Carbon From Cracking.

\section{Subtask 3.7.1. PFB Methane Cracking}

The objective of this subtask is to determine operating conditions needed to crack the hydrocarbon gases from the PFH process to generate hydrogen and carbon by conducting laboratory-scale tests. An existing laboratory-scale reactor will be modified to include continuous gas flow through a batch fluidized bed. On-line gas detectors will be used to collect data during the cracking and combustion tests.

\section{Discussion}

During the quarter, all of the equipment required for the cracking apparatus was received. The external thermocouples and the differential pressure gauge/controller were installed and assembly of the reactor was completed. Instrumentation for the equipment was checked and found to be operational. The unit was pressure tested and the mixture of combusted shale ( 25 weight percent) and silica sand ( 75 weight percent) to be used as a bed material was prepared.

The first two cracking tests were conducted at $1775^{\circ}$ and $1950^{\circ} \mathrm{F}$ at a pressure of 200 psig. Although fluidization was maintained throughout the heat-up and steady-state periods, the silica sand fused in both tests. Gas samples were taken during the tests and the product gas and bed material were submitted for analyses.

In the next series of tests, the silica sand was replaced with alumina beads $(-40+60$ mesh) to eliminate fusing of the bed material at high temperatures. Five successful tests were conducted in the cracking reactor at temperatures of $1700^{\circ}$ to $1950^{\circ} \mathrm{F}$ and pressures of 50 to $1000 \mathrm{psig}$. Steady-state periods ranging from 10 to 20 minutes were used for the tests because carbon 
deposited from the cracking reaction bullt up quickly in the reactor. The tests were completed successfilly and no solids sintering was experienced.

Preliminary results confirm that the extent of methane cracking increases with increasing temperature and decreases with increasing pressure. Detailed results of the cracking tests will be presented when the chemical analyses are complete.

Next quarter, IGT will complete tests in the range of cracking conditions of interest and determine the effects of shale/alumina ratio on the cracking reaction. The draft final report for this subtask will be prepared.

\section{Subtask 3:7.2. PFBC of Carbon From Cracking}

The objectives of this subtask are to demonstrate the removal of deposited carbon from the surface of the spent beneficlated shale by combustion and to evaluate shale for cracking effectiveness and particle stability through multiple cycles of cracking and combustion. The apparatus being built for tests in Subtask 3.7 .1 will also be used for these tests.

\section{Discussion}

This subtask was originally scheduled to be inftiated in December 1992. Due to the reduction in program work scope, it will not be initiated.

\section{Subtask 3.9. Catalytic Hydroretorting}

The objective of this subtask is to improve the quality of PFH-produced shale oil in-situ by utilizing catalysts. Tests will be conducted in a small laboratory-scale hydroretorting unit using hydrotreating catalysts. These catalysts will be used in the retort 1 tself and will be of two types, regenerable and throw-away.

\section{Discussion}

IGT conducted six catalytic hydroretorting tests during the quarter using throw-away catalysts. Catalyst loadings were $1000 \mathrm{ppm}$ (weight basis) for the first five tests and 10,000 ppm for the sixth test. Catalysts were selected from the list of potential catalysts identified previously. The effects of the catalysts on oil yield and quality will be summarized in the draft final report on this subtask.

The catalyzed-shale tests were conducted in an existing laboratory-scale reactor. Test conditions of $925^{\circ} \mathrm{F}$ and $1000 \mathrm{psig}$ with a 20 -minute residence time were used in these tests to ensure a common basis for comparing the oil yields and properties to those of tests with no catalyst present. Five replicate baseline tests with noncatalyzed beneficiated shale were conducted previously to provide a statistically valid bench mark for comparing the effects of various catalysts. The oil yleld from the baseline tests averaged 58.6 gallons per ton (standard deviation of 0.35 gallon per ton). The specific gravity and carbon-to-hydrogen ratio of the oil were $1.004 \mathrm{~g} / \mathrm{mI}$ and 8.97, respectively. 
Also during the quarter, seven catalytic hydroretorting tests were conducted with regenerable catalysts. In the first three tests, 25 grams of catalyst were placed in the reactor exit 1 ine, and 100 grams of shale were charged to the batch PFH reactor. Reactor conditfons and flows were such that the exit line was heated to about $800^{\circ} \mathrm{F}$. At this temperature, the oil would pass through the catalyst as a vapor. The catalysts placed in the exit line included nickel-molybdenum and cobalt-molybdenum commercial catalysts and a caralyst developed at IGT.

Preliminary results of these tests showed that all three catalysts improved the product oil quality. The commercial catalysts performed better than the catalyst produced by IGT. The commercial Co-Mo catalyst removed more sulfur and nitrogen from the oil than the Ni-Mo catalyst.

The fourth test was conducted in bed using the commercial Co-Mo catalyst. In this test, 25 grams of catalyst was ground to -20 mesh and mixed with 100 grams of shale by hand. This allowed simultaneous introduction of catalyst and shale to the batch PFH retort. The liquids and gases produced during the test were collected. Preliminary results show that the catalyst produced some decreases in the sulfur and nitrogen contents of the oil, but the effects were not as great as when the catalyst was placed in the exit gas line.

The other three batch PFH tests were conducted under similar conditions with a commercial $\mathrm{Ni}$-Mo catalyst, a tungsten-promoted $\mathrm{Ni}$-Mo catalyst, and a Co-Mo catalyst. Detailed results of the tests conducted in this subtask will be presented in the draft final report.

\section{Subtask 3.10. Autocatalysis in Hydroretorting}

The objective of this subtask is to investigate the effects of potentially catalytic minerals or alkali metal oxides naturally present in shale on hydroretorting characteristics and product yields. Tests will be conducted in an existing laboratory-scale batch reactor using as-received shale and shale impregnated with potentially catalytic metals.

\section{Discussion}

During the quarter in preparation for autocatalytic hydroretorting tests, UA dried a $4-\mathrm{kg}$ batch of beneficiated Alabama shale at $80^{\circ} \mathrm{C}$ in an argon atmosphere. The moisture content of the as-received sample was about $44 . \mathrm{J}$ weight percent. About 500 grams of the resulting dry cake were crushed in a glove box purged with nitrogen; about 100 grams were crushed in air to determine the effects of atmospheric oxidation on subsequent autocatalysis tests. Both samples were analyzed for carbon and hydrogen content in a LECO analyzer. The results indicate that there was no appreclable oxidation of shale due to the presence of atmospheric oxygen duxing crushing.

Becalse $C_{6}$ to $C_{14}$ hydrocarbons will likely be present in the oil produced during autocatalysis tests, UA prepared a mixture of some typical paraffinic and aromatic compounds to calibrate the chromatograph. The flow rate of hydrogen into the reactor was cali. rated at about 0.5 standard liters per minute. 
Also during the quarter, UA identified four metals as potential catalysts for shale hydroretorting. Autocatalysis tests were conducted with two of the metals. Next quarter, UA will conduct tests with the other two metals concurrent with preparation of the draft final report for this subtask.

\section{Subtask 3.11. Shale Oil Upgrading and Evaluation}

The objective of this subtask is to investigate conventional and novel methods for upgrading the oil produced by shale hydroretorting. This subtask is divided into two subtasks: 3.11.1. Conventional Upgrading, and 3.11.2. Novel Approach to Upgrading.

\section{Subtask 3:11.1. Conventional Upgrading}

The objective of this subtask is to evaluate conventional hydrotreating technology for upgrading shale oil produced from the PFH process to transportation fuel.

\section{Discussion}

During the quarter. IGT conducted oil upgrading tests with conventional catalysts. The catalysts used in the tests included two commercially available oil hydrotreating catalysts and one catalyst prepared at IGT. The hydrogen upgrading tests were conducted at a pressure of $2000 \mathrm{psig}$ and a temperature of $750^{\circ} \mathrm{F}$.

One of the commercial catalysts contains nickel; the other cobalt. Preliminary results of the tests conducted with these catalysts show that the ofl quality was improved; however the Ni-containing catalyst was more effective. The raw shale oil had a specific gravity of $0.996 \mathrm{~g} / \mathrm{mL}$ and contained 2.75 weight percent sulfur and 1.44 weight percent nitrogen. The Ni-containing catalyst reduced the specific gravity to $0.895 \mathrm{~g} / \mathrm{mL}$ and decreased the sulfur and nitrogen contents by 89 and 72 percent, respectively. The Co-containing catalyst reduced the specific gravity to $0.920 \mathrm{~g} / \mathrm{mL}$ and decreased the sulfur and nitrogen contents by 84 and 57 percent, respectively.

\section{Subtask 3.11.2. Novel Upgrading}

The objective of this subtask is to determine if the whole product oil can be hydrotreated in a novel one-step catalytic process without the use of hydrogen or severe operating conditions.

\section{Discussion}

During the quarter, IGT conducted five ofl upgrading tests, including four tests that were operationally successiul. The first test was not successful because product oil could not be consistently discharged from the oil collection system. The oil collection system was retubed after the first test to correct the problem.

The four successful oil upgrading tests included three tests in hydrogen and one test in methane. The catalysts used in the tests included two comer- 
cially available oll hydrotreating catalysts and one catalyst prepared at IGT. The hydrogen upgrading tests were conducted at a pressure of $2000 \mathrm{psig}$ and a temperature of $750^{\circ} \mathrm{F}$. The fourth successful test was conducted with an IGTprepared catalyst with methane at a fressure of $1000 \mathrm{psig}$ and a temperature of $750^{\circ} \mathrm{F}$. Steady-state periods of two to four hours were achleved for each of the tests.

One of the commercial catalysts contains nickel; the other cobalt. Preliminary results of the tests conducted with these catalysts show that the oil quality was improved; however the $\mathrm{Ni}$-containing catalyst was more effective. The raw shale o1l had a specific gravity of $0.996 \mathrm{~g} / \mathrm{mL}$ and contained 2.75 weight percent sulfur and 1.44 weight: percent nitrogen. The Ni-containing catalyst decreased the specilic gravity to $0.895 \mathrm{~g} / \mathrm{mL}$ and decreased the sulfur and nit:ogen contents by 89 and 72 percent, respectively. The Co-containing catalyst decreased the specific gravlty to $0.920 \mathrm{~g} / \mathrm{mL}$ and decreased the sulfur and nitrogen contents by 84 and 57 percent, respectively.

Three tests were also conducted this quarter with catalysts prepared at IGT specifically for use in a methane atmosphere. The first test was performed using methane alone as the feed gas. In the other two tests, steam was added to help reduce coking during upgrading. The three tests were conducted at $750^{\circ} \mathrm{F}$ and a pressure of 1000 psig.

The first test in methane showed no improvement in the oil specific gravity and only small decreases in the ofl nitrogen and sulfur contents. Significant coking was observed. A different catalyst was used for the second test and steam was added to reduce coking. Coking again occurred and only minimal improvements in the oil properties were achieved.

The third test was a replicate of the second test because of poor pressure control in the second test. The product yields of the replicate test were similar to that of its predecessor.

IGT also conducted seven tests with a commercial Ni-Mo catalyst and a W-promoted Ni-Mo catalyst. The goal of the tests was primarily to upgrade the light shale oil fraction, boiling below $650^{\circ} \mathrm{F}$. The first two tests were made in a hydrogen atmosphere at $2000 \mathrm{psig}$ with the $\mathrm{Ni}$-Mo and W-promoted catalysts at $750^{\circ} \mathrm{F}$. The third test was conducted in a hydrogen atmosphere at $2000 \mathrm{psig}$ with the W-prowoted Ni-Mo catalyst at $700^{\circ} \mathrm{F}$.

Four other upgrading tests were performed in a methane atmosphere at $1000 \mathrm{psig}$. Two tests were conducted with the Ni-Mo catalyst at $750^{\circ}$ and $800^{\circ} \mathrm{F}$. Some coke formation occurred during the test at $750^{\circ} \mathrm{F}$. However, in the test conducted at $800^{\circ} \mathrm{F}$, coke formation was so extensive that the reactor plugged and the test had to be terminated. The last two tests were replicate tests in methane at $750^{\circ} \mathrm{F}$ using a catalyst developed at IGT. No coke was observed on the catalyst a ter these tests.

Next quarter, oll upgrading tests will be completed and will continue to focus on the shale oil fraction boiling below $650^{\circ} \mathrm{F}$. The oil upgrading characteristics of several IGT-developed catalysts will be evaluated in methane for resistance to coking. The final report for this subtask will be prepared. 
Task 4. Beneficiation Research

The objective of this task is to test several novel and advanced grinding and beneficiation concepts for processing Eastern oil shales. The ultimate goal is to develop a minimum-cost system for delivering shale concentrates of suitable form to the PFH process. The University of Alabama Mineral Resources Institute (MRI) has primary responsibility for this program task.

The active work in this task is divided into four subtasks: 4.1. Grinding Studies, 4.2.1. Column Flotation Tests, 4.4. Integrated Grinding and Flotation, and 4.7. Economic Analysis. Subtask 4.4 is being conducted by the University of Kentucky. Center for Appiled Energy Research (UK-CAER).

\section{Subtask 4.1. Grinding Studies}

This subtask is divided into three subtasks: 4.1.3. Stirred Ball Mill Grinding, 4.1.5. Alternative Technology Evaluation, and 4.1.6. Ultrafine Size Separation.

\section{Subtask 4.1.3. Stirred Ball Mill Grinding}

During the quarter, MRI obtained and installed a larger capacity ( $/$ HP) agitation unit for the Denver flotation cell so that the required rotation could be achieved when working with the continuous mill. The original agitation unit did not have sufficient power ( $/ \mathrm{HP}$ ) to maintain the required rpm under load.

Also, a larger motor (1/ HP) was installed on the small-scale polyurethane lined mill ( $1.6-\mathrm{L}$ capacity) for continuous runs. Efforts are also underway to connect the motor with a data acquisition system for power measurements. A sample of shale having a $d_{90}$ of 40 micrometers $(\mu \mathrm{m})$ at 55 percent solids was prepared for the grinding runs.

Once these modifications were made, MRI completed the planned stirred ball milling tests and began preparation of the draft final report for this subtask.

\section{Subtask 4.1.5. Alternative Technology Evaluation}

The objective of Subtask 4.1 .5 is to evaluate several alternative comminution technologies to determine which could replace conventional technologies in the oil shale beneficiation scheme.

MRI completed a reduced scope of work on this subtask and is preparing a draft final report based on the results.

\section{Subtask 4.1.6. Ultrafine Size Separation}

MRI found that some data included in the quarterly report for June August 1992 for hydrocyclone tests conducted with the 14.3-mm vortex finder were biased due to excessive heating of the slurry by the 1 h-inch centrifugal pump. In control tests conducted subsequently, MRI found that slurry tempera- 
ture significantly affected the size distribution of the solids in the overflow stream from the hydrocyclone. Increasing the slurry temperature from $7^{\circ}$ to $42^{\circ} \mathrm{C}$ increased the $-12 \mu \mathrm{m}$ fraction in the cyclone overflow from 56.1 to 66.8 weight percent. Over the same temperature range, the $+24 \mu \mathrm{m}$ fraction decreased from 19.6 to 10.2 weight percent. The effect is likely due to decreased viscosity of the slurry due to increased temperature.

MRI conducted batch tests with a smaller centrifugal pump ( 1 inch) and the $14.3-\mathrm{mm}$ vortex finder. The results showed that the apex spigot of $9.4 \mathrm{~mm}$ (rather than $6.4 \mathrm{~mm}$ ) and a cyclone feed pressure of $15 \mathrm{psig}$ (rather than 10 psig) would be required to yield the desired results. Even though a smaller pump was employed in this series of tests, the slurry temperature increased from $23^{\circ}$ to $32^{\circ} \mathrm{C}$ within about 20 minutes.

Based on the results of the second batch test series, the bulk sample of -150 -mesh slurry was hydrocycloned continuously at a pressure of $25 \mathrm{psig}$. The results showed that 39.7 percent of the feed solids reported to the overflow stream; the $d_{90}$ was $21.5 \mu \mathrm{m}$.

MRI also conducted studies in the rod mill with the secondary cyclone underflow product to determine the time required to reduce this product to -24 $\mu \mathrm{m}$. The secondary cyclone underflow was ground to $-24 \mu \mathrm{m}$ and mixed with the combined cyclone overflow to yield a flotation feed product for the column cell.

MRI conducted column flotation tests to confirm the viability of a twostage flotation circuit. Rougher flotation has been completed but cleaner and scavenger flotatinn tests will extend into next quarter. MRI also began analyzing the data collected previously for inclusion in the draft final report for this task.

\section{Subtask 4.2.1. Column Flotation Tests}

This subtask is divided into two subtasks: 4.2.1.1. Column Flotation Modeling, and 4.2.1.2. Circuit Evaluation - Indiana Shale.

The primary objective of Subtask 4.2.1.1 is to develop a steady-state phenomenological model of column froth flotation for ultrafine ground shale, which relates the behavior of various classes of particles to column operating parameters. Another objective is to develop an on-line procedure for measuring the oil content of a shale sample on the basis of $x$-ray back-scattering intensity. The objectives of Subtask 4.2.1.2 are to test the applicability of grinding circuits developed for Alabama shale to Indiana shale and to modify the circuits for the specific grinding and kerogen liberation characteristics of Indiana shale.

\section{Discussion}

MRI conducted one test to determine the residence time distribution of solid particles in the deep froth flotation column. The operating parameters were an air flow rate of 4.5 standard liters per minute, slurry feed rate of $250 \mathrm{~mL} / \mathrm{min}$, and a tailings rate of $250 \mathrm{~mL} / \mathrm{min}$. Dowfroth 250 was added at 60 
ppm. Fifteen grams of silica sand $(-37 \mu \mathrm{m})$ were injected into the column at time zero. Slurry samples were taken at specific time intervals during the next 30 minutes. The preliminary results show that the solids residence time in the column was about 7 minutes; that of the liquid was about 12.8 minutes.

MRI has completed the experimental work for this subtask and will prepare the draft final report next month.

\section{Subtask 4.4. Integrated Grinding and Flotation}

The objective of this subtask is to continue the development of the integrated grinding and flotation SYMUSEP process and to investigate methods for dewatering the resultant kerogen/water slurry. Subtask 4.4 is divided into three subtasks: 4.4.1. Acquisition and Characterization of Samples, 4.4.2. SYMUSEP Separator Testing, 4.4.3. Pilot Plant Studies, and 4.4.4. Dewatering Studies.

\section{Discussion}

Column Flotation Studies: The SYMUSEP separator built at UK-CAER did not perform satisfactorily when initially tested. Therefore, UK-CAER obtained the original SYMUSEP separator from B. Datta Research and installed it in the laboratory. In the initial tests with the original SYMUSEP separator, air was added directly into the grinding section for fine bubble generation rather than using a sparger for bubble generation. The results indicated that using an air flow rate of $3 \mathrm{~L} / \mathrm{min}$ in the SYMUSEP separator provided a yield of 76 percent. However, the concentrate contained only 25.1 percent carbon.

UK-CAER also conducted tests using the SYMUSEP separator as a grinding/ rougher flotation stage followed by the Ken-Flote column as a scavenger flotation stage to recover carbon from the tallings stream produced by the SYMUSEP separator. At grinding speeds of 200 to $340 \mathrm{rpm}$, the froth produced in the rougher flotation stage contained 26 to 30 percent carbon with a recovery of 44 to 46 percent. The recovery in the scavenger stage was 75 to 85 percent with concentrate grades of 17 to 20 percent carbon. Combining the froth produced by the rougher and scavenger stages gave an overall recovery of 96 percent with a concentrate grade of 24 percent carbon.

UK-CAER conducted an analysis on a sample of finely ground ( 90 percent $-10 \mu \mathrm{m})$ oil shale to determine the grade-recovery relationship and define the limits of both recovery and grade using froth flotation. The analysis showed that if a concentrate grade of 30 percent carbon is desired, the maximum recovery that could be achieved with flotation at this grind would be 75 percent. For a concentrate grade of 40 percent carbon, the maximum recovery decreases to 45 percent. Results close to the limits defined by the release analysis were obtained using the SMUSEP separator as a rougher flotation stage followed by the Ken-Flote column as a scavenger flotation stage and combining both froth products.

Dewatering Studies: UK-CAER conducted basic surface characterization of the kerogen concentrate obtained in the pilot-scale flotation tests. The concentrate showed a point-of-zaro charge (PZC) at a $\mathrm{pH}$ of 3.0 . The PZC is a 
value above which particles are negatively charged and below which they are positively charged. In the presence of $10^{-4} \mathrm{M} / \mathrm{L}(50 \mathrm{ppw}) \mathrm{Cu}^{+2}$ lons, the PZC occurred at $\mathrm{pH}$ of 3,5 , and 10.5. These data indicate that with copper ions, there are $3 \mathrm{pH}$ values at which there will be zero charge on particles and dewatering of the concentrate will be relatively easy. In the presence of $10^{-4}$ $\mathrm{M} / \mathrm{L}$ of $\mathrm{Al}^{+3}$ ions, the $\mathrm{PZC}$ occurred at $\mathrm{pH} 4.5$ and 9.0 .

Pressure filtration tests were conducted with the kerogen slurry to determine the effect of cake chickness. Cake molsture decreased from 44 to 40 percent as the cake thickness was increased from 0.25 to $0.7 \mathrm{~cm}$. As filtration time was varied from 1 to 5 minutes, cake molsture remained constant at 40 percent. Using the optimum conditions determined from these tests (2 minutes filtration time and $0.5-\mathrm{cm}$ cake thickness), pressure was varied from 10 to 60 psig; moisture decreased from 75 to 37.4 percent. The optimum pressure was determined to be $40 \mathrm{psig}$, which gave filter cake containing 40 percent moisture. These dewatering results vary considerably from those reported previously and can be attributed, in part, to a reduction in the $\mathrm{pH}$ of the slurry from 6.5 to 3.0 due to oxidation during storage.

UK-CAER continued tests to determine the effects of an anionic surfactant (sodium 2-ethylhexyl sulfate) on pressure filtration. At a surfactant dose of $1 \mathrm{~kg} / t o n$, the moisture content of the cake was reduced from 43 to 39 percent. Increasing the surfactant dose above this level did not further reduce the moisture content. The $\mathrm{pH}$ of the oil shale concentrate did not have any significant effect on cake moisture since the solid particulates are negatively charged from $\mathrm{pH} 3$ to 11 and electrostatic repulsive forces prevent increased surfactant adsorption.

A few tests were also conducted in which an electirc field was applied during pressure filtration. UK-CAER found that an electric field ( 120 volts, $1 \mathrm{amp}$ ) applied across the filter cake during pressure filtration reduced the cake moisture to as low as 36 percent. Increasing the current to 3 amps further reduced the moisture to 34.5 percent. Cakes with moisture contents as low as 25 percent have been obtained with this approach. UK-CAER will summarize these results in the final report.

\section{Subtask 4.7. Economic Analysis}

The objective of this subtask is to update the estimate of the cost of beneficiating Alabama shale to reflect the effects of current technological development.

\section{Discussion}

During the quarter, MRI corrected some of the capital cost figures that were presented in the quarterly report for June - August 1992. The corrected capital cost is 6.3 percent higher than that estimated in 1988 by Johnson and Riley (Roberts and Schaefer Company). 1 The operating cost estimate increased by only 0.2 percent, because costs that increased were offset by a decrease in the cost of power purchased locally. 
Also, MRI combinel the capital and operating costs to show the cost of concentrates delivered to the hydroretorting operation. The capital cost of concentrate was obtained by calculating the cost of amortizing the capital investment over a 25-year period at various assumed rates of interest. The Roberts and Schaefer report assumed an interest rate of 15 percent. However, current economic conditions (ie., prime rate at 6 percent) make it realistic to assume lower rates for the cost of capital. The cost of delivered concentrates was, therefore, calculated at 15, 12, 10 and 8 percent interest. At current conditions, the cost of concentrates could be lower than the $\$ 34.95 /$ ton estimated by Johnson and Riley.'

MRI continued to review the Roberts and Schaefer report to establish equipment substitutions that could be made in estimating the effect of technology advances on the cost of oll shale beneficlation. MRI will prepare the draft final report on this subtask next month.

\section{Task 6. Environmental Data and Mitigation Analyses}

The overall objective of this task is to obtain environmental data relating to PFH and to shale beneficiation and to analyze the potential environmental impact of the integrated PFH process. This task consists of four subtasks: 6.2.2. Wastewater Treatability, 6.2.3. Waste Management Facility Conceptual Design, 6.4.1 PFH Process Analyses, and 6.4.4. Economics. Subtasks 6.2 .2 and 6.2 .3 are being conducted by the Tennessee Technological University (TTU).

\section{Subtask 6.2. Water Availability and Treatment Studies}

\section{Subtask 6.2.2. Wastewater Treatability}

The objective of this subtask is to determine suitable techniques for treating wastewater generated during shale processing.

\section{Discussion}

TTU continued attempts to acclimate microorganisms to the stripped PFH waste water during the quarter. Shaker flasks with 5,10 , and 25 percent (by volume) of the stripped $P F H$ waste were maintained and evaluated for microbial growth. Acclimation as evidenced by substantial drops in the chemical oxygen demand (COD) in the shaker flasks was not observed.

TTU also conducted tests to determine if microorganisms would use 4-methyl pyridine as a nitrogen source. A shaker flask was prepared with 250 $\mathrm{mg} / \mathrm{L}$ of phenol and $50 \mathrm{mg} / \mathrm{L}$ of 4 -methyl pyridine along with other essential nutrients. A biological seed was taken from a combination of activated sludge from the local sewage treatment plant, cow and horse manure, and soil. No growth has been observed to date.

TIU conducted a treatability study on a combination synthetic waste with phenol and MEK at an initial concentration of about $250 \mathrm{mg} / \mathrm{L}$, and aniline and 4-methyl pyridine at about $300 \mathrm{mg} / \mathrm{L}$. The COD decreased from an initial total value of 1937 to $63 \mathrm{mg} / \mathrm{L}$ after about 94 hours. This COD reduction was associ- 
ated with a simultaneous reduction in the concentration of the organic compounds. The concentration of the 4-methyl pyridine was greater than the residual concentration of COD after 94 hours. This would be expected since this compound is only partially oxidized during the COD test. Figure 6-1 shows the change in $C O D$ and the concentration of the organic compounds during the experiment.

The MEK concentration decreased to less than $1 \mathrm{mg} / \mathrm{L}$ after about 43 hours. Once the MEK was depleted, the rate of removal of phenol and aniline increased. Their concentrations decreased to less than $1 \mathrm{mg} / \mathrm{L}$ after about 94 hours. The change in the concentration of these compounds with respect to time is shown in Figure 6-2. The data presented in the figures were corrected for the air stripping of MEK.

The concentration of 4-methyl pyridine decreased about 46 percent during 109 hours. This reduction could have been the result of biodegradation or bioadsorption. The data in Figure 6-3 shows that the reduction in 4-methyl pridine concentration was not the result of air stripping. Further tests will be required to determine the mechanism responsible for this reduction.

Two compatibility studies were performed. The first was with phenol and MEK in combination at initial concentrations of about $250 \mathrm{mg} / \mathrm{L}$. The results of this experiment (Figure $6-4$ ) show that the COD was reduced from an initial concentration of 1043 to $19 \mathrm{mg} / \mathrm{L}$ in about 37 hours. During this same period, the MEK and phenol concentrations were reduced from an initial 222 and 254 $\mathrm{mg} / \mathrm{L}$, respectively, to less than $1 \mathrm{mg} / \mathrm{L}$ each.

The second compatibility study was with phenol and aniline at concentrations of about 250 and $300 \mathrm{mg} / \mathrm{L}$, respectively. The results (Figure 6-5) show that the COD was reduced from an initial 1269 to about $80 \mathrm{mg} / \mathrm{L}$ after 89 hours. Phenol decreased from an initial concentration of 248 to less than $1 \mathrm{mg} / \mathrm{L}$ in about 42 hours. Aniline was reduced from an initial concentration of 297 to less than $1 \mathrm{mg} / \mathrm{L}$ in about 89 hours.

The data in Figures $6-4$ and $6-5$ suggest that under the conditions of the experiment MEK will be preferentially biodegraded before phenol and that phenol will be biodegraded before aniline. More research is needed to confirm these results.

\section{Subtask 6.2.3. Waste Management Facility Conceptual Design}

The objective of this subtask is to design a conceptual wastewater and process water treatment facility for a commercial-scale PFH plant.

\section{Discussion}

Cooling Water Quality Criteria: About 7.55 MGD of makeup water are required for the open recirculating cooling system of the combined PFH plant 


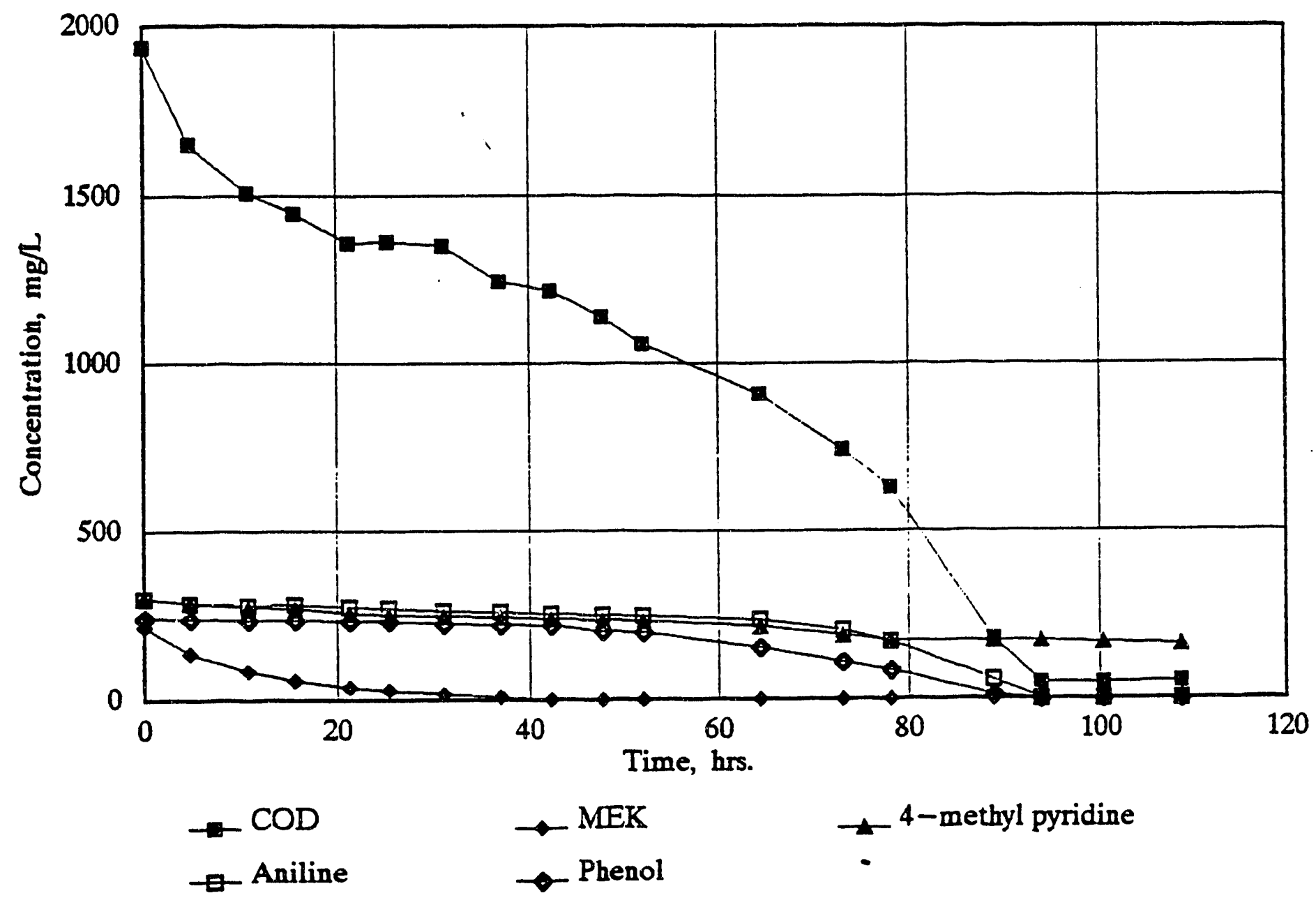

Figure 6-1. CHANGE IN COD, PHENOL, MEK, ANILINE AND 4-METHYL PYRIDINE CONCENTRATIONS WITH TIME DURING 4-WAY COMBINATION EXPERIMENT 


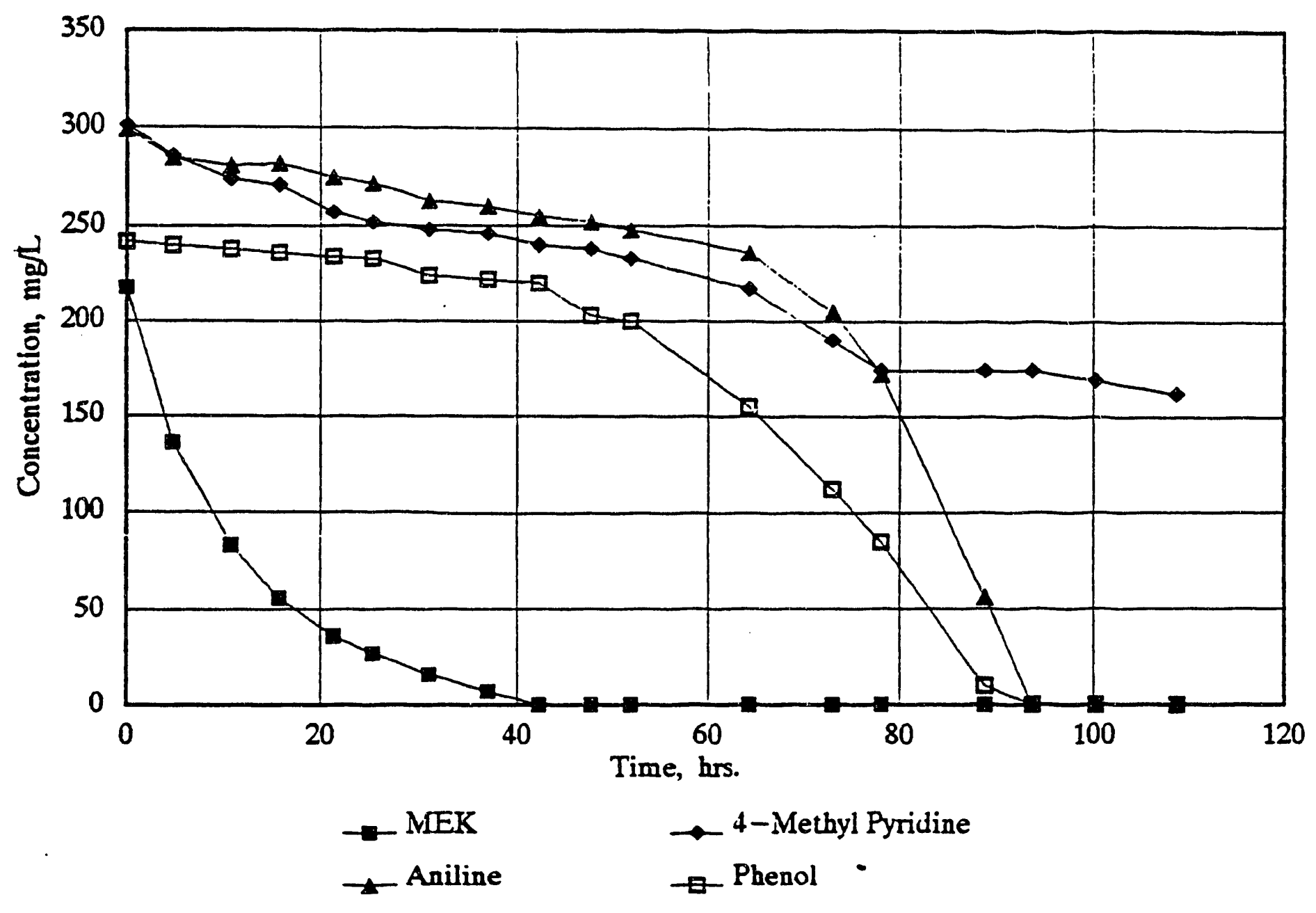

Figure 6-2. CHANGE IN PHENOL, MEK, ANILINE AND 4-METHYL PYRIDINE CONCENTRATIONS WITH TIME DURING 4-WAY COMBINATION EXPERIMENT 


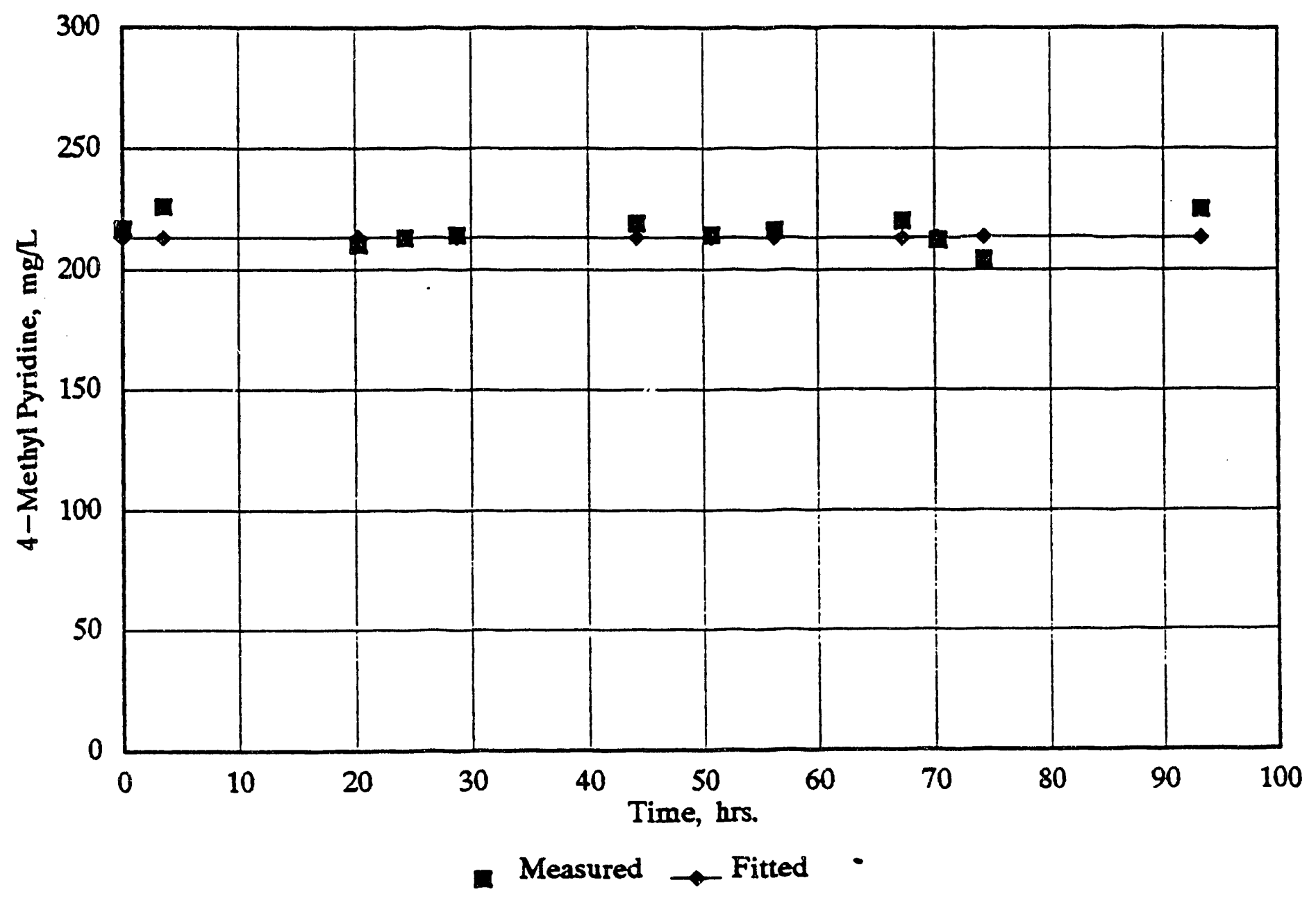

Figure 6-3. CHANGE IN 4-METHYL PYRIDINE CONCENTRATION WITH TIME DUE TO AIR STRIPPING AT AN AIR FLOW RATE OF ABOUT $257 \mathrm{~mL} / \mathrm{min} / \mathrm{L}$ 


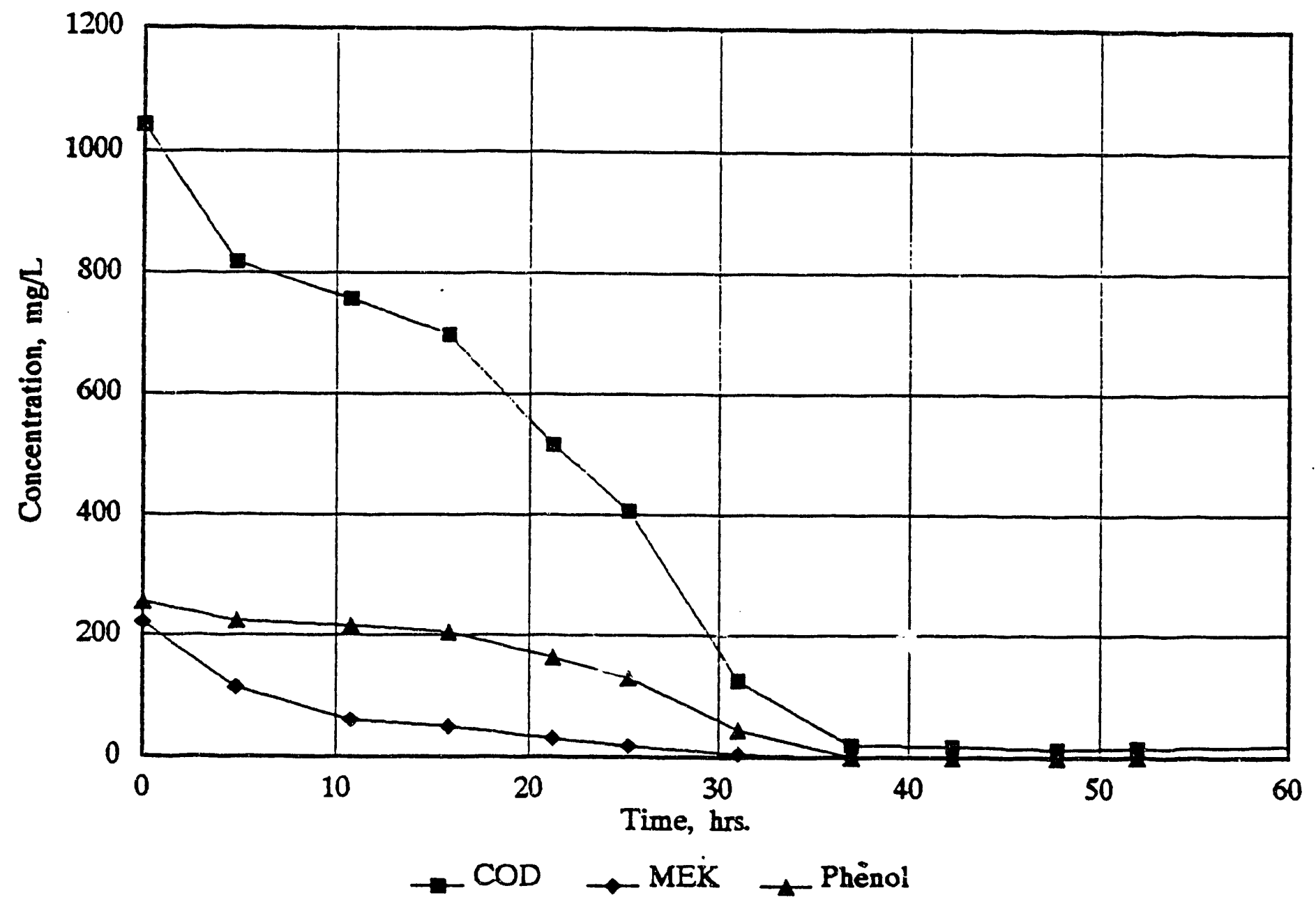

Figure 6-4. CHANGE IN COD, PHENOL, AND MEK CONCENTRATIONS WITH TIME DURING COMBINATION EXPERIMENT WITH PHENOL AND MEK (Data were corrected for air stripping of MEK) 


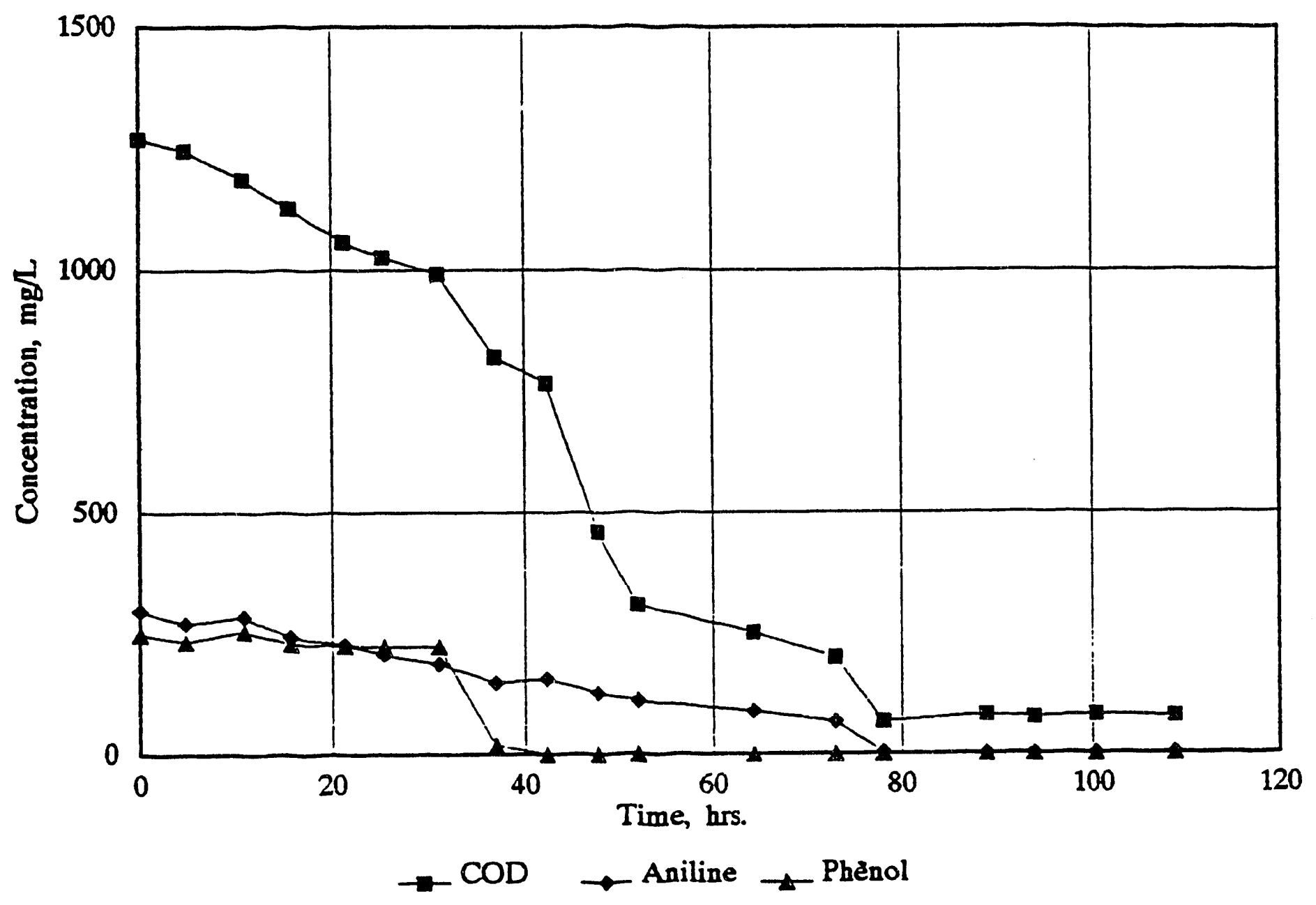

Figure 6-5. CHANGE IN COD, PHENOL, AND ANILINE CONCENTRATION WITH TIME DURING COMBINATION EXPERIMENT WITH PHENOL AND ANILINE 
and steam power plant. This makeup cooling water should be of such quality as to avoid the three major water-related cooling water system problems corrosion, scale, and fouling. A brief description of each is given below.

For an open recirculating system that requires substantial makeup water, corrosion presents a serious problem. Oxygen presents the most serious threat. At elevated temperatures and at points of high heat transfer, oxygen can cause severe pitting corrosion. In addition to pitting corrosion, galvanic corrosion can occur due to high concentrations of total dissolved solid;. Corrosion may also occur due to alkall attack.

Scale formation presents a significant problem for cooling water systems with high makeup flow rates. Scale forms from the precipitation of compounds that become insoluble at higher temperatures, such as calcium carbonate. Additional scale-related problems are associated with the presence of ions such as $\mathrm{Ca}$ and magnesium, which can combine with avallable phosphate, silica, sulphate, and carbonate to form hard heat-transfer-limiting scale. In general, for open recirculating systems, the $\mathrm{Ca}$ and $\mathrm{Mg}$ hardness should be low enough so that a cooling tower can operate with the circulating water equal to at least several concentrations of makeup before scale forms at a significant rate. Table 6-1 lists some of the important variables that must be controlled to prevent significant scale formation.

\section{Table $6-1$. PARAMETERS THAT INFLUENCE SCALE FORMATION ${ }^{2}$}

$$
\begin{aligned}
& \frac{\text { Variable }}{\mathrm{Ca}, \mathrm{Mg}} \\
& \mathrm{M}, \mathrm{PH}, \mathrm{T} \\
& \mathrm{SO}_{4}, \mathrm{SiO}_{2}
\end{aligned}
$$

\section{Effects}

Define scaling tendency of water.

Define concentrations of carbonate and bicarbonate, and solubility of $\mathrm{CaCO}_{3}$.

Must be controlled to prevent sulfate and silicate scales.

$\mathrm{Ca}$ and $\mathrm{Mg}$ hardness define the scaling tendency of the water. Total alkalinity (M), $\mathrm{pH}$, and temperature (T) define the concentrations of carbonate and bicarbonate ions in the water, and also the solubility of $\mathrm{CaCO}_{3}$. All of these must be controlled within acceptable ranges to ensure scale-free operation. Concentrations of sulfate and silica must also be controlled to prevent formation of gypsum and silica scale.

Fouling has the same effect on cooling water systems as scaling, but fouling also promotes severe corrosion under the deposits. Fouling results from the settling out of suspended solids, build up of corrosion products, and growth of microbial masses. Table 6-2 shows some sources of foulants in a typical recirculating system.

Fouling problems are complicated by microbial activity. Slime deposits on tubes not only interfere with efficient heat transfer, but also act as a trap to enmesh suspended solids, further impeding heat transfer. In addition, by-products of bacterial metabolism influence water chemistry, including the tendency for scale to form or metal to corrode. 
Table 6-2. SOURCES OF FOULING DEPOSITS ${ }^{2}$

\begin{tabular}{|c|c|c|}
\hline Raw Water & Airborne & Recirculating Water \\
\hline $\begin{array}{l}\text { Colloidal organics } \\
\text { organics }\end{array}$ & Dirt & $\begin{array}{l}\text { Scale: } \mathrm{CaCO}_{3}, \mathrm{CaSO}_{4} \text {, } \\
\mathrm{MgSiO}_{3}\end{array}$ \\
\hline Silt, dirt & $\begin{array}{l}\text { Reactive gases } \\
\mathrm{H}_{2} \mathrm{~S}, \mathrm{SO}_{2}, \mathrm{NH}_{3}\end{array}$ & $\begin{array}{l}\text { Corrosion product: } \\
\mathrm{Fe}_{2} \mathrm{O}_{3}\end{array}$ \\
\hline Soluble iron & & $\begin{array}{l}\text { Process leaks - } \\
\text { hydrocarbons, sulfides }\end{array}$ \\
\hline $\begin{array}{l}\text { Microbial } \\
\text { contamination }\end{array}$ & $\begin{array}{l}\text { Microbial } \\
\text { contamination }\end{array}$ & Microbial deposits \\
\hline
\end{tabular}

Corrosion, scale, and fouling rarely occur independently of one another. Usually two or three develop together to cause loss of heat transfer and premature metal loss. Therefore, special care must be taken to avoid corrosion, scale, and fouling causing contaminants.

Makeup water control programs for cooling systems vary considerably because each installation presents different environmental factors and operating problems. A common method used within industry for the determination of the scaling tendency and corrosiveness of a water is the use of two calculable indexes - the Langelier and Ryznar. Both indexes make use of chemical equilibrium principles.

The Langelif: Index makes use of the fact that each natural water supply is completely stable with respect to $\mathrm{CaCO}_{3}$ solubility at a certain $\mathrm{pH}\left(\mathrm{pH}_{3}\right)$. The $\mathrm{pH}_{3}$ can be calculated from water quality data, including calcium content, total alkalinity, temperature and total dissolved solids. Once the $\mathrm{pH}_{3}$ of the water is determined, it can be compared with the actual $\mathrm{pH}$ of the water. The Langelier Index is calculated from $\left(\mathrm{pH}-\mathrm{pH}_{\mathrm{s}}\right)$. If the result is positive, the water is a scaling water - it is over saturated with respect to $\mathrm{CaCO}_{3}$. If the result is negative, the water is under saturated with respect to $\mathrm{CaCO}_{3}$ and will attack the metal of the system in the presence of oxygen in an attempt to obtain equilibrium. Therefore, the water in this condition is corrosive and the more negative the number the more corrosive the water. ${ }^{3}$

The Ryznar Index is a modification of the Langelier Index. Its intent is to reliably predict the likelihood of scale formation and corrosion in flowing systems. The Ryznar Index is calculated from (2 $\left.\mathrm{pH}_{\mathrm{z}}-\mathrm{pH}\right)$. Ryznar Index numbers of about 7 indicate that the water is quite stable, neither corrosive nor scaling. The water becomes progressively more scale forming as the index drops below 6 and becomes progressively more corrosive as the index increases above 7.4

Due to the extreme temperature changes that occur within cooling systems, scale and corrosion control by the Langelier and Ryznar Indexes alone rarely offer a satisfactory solution. This is because the $\mathrm{pH}_{3}$ is temperature dependent. The next step taken is chemical treatment of the water, 2,4 which 
Involves the addition of entifoulants, corrosion inhibitors, and microbicides to the makeup watse. Chemical treatment of cooling water is beyond the scope of the current project.

Since the "bact nature of the cooling system for a comercial PFH plant has not yet hee., defined, water treatment will involve providing water that is neither scale forming nor corrosive as indicated by the Langelier and Ryznar Indices. in addition, the water should be low in total solids and free from micruofal contamination. Nater of this quality is required for any open recirculating cooling systein. As the cooling system is defined, an appropriate chemical treatment program can be developed.

Import Water Cuality: The import water requirement for a combined PFHpower plant is estimated to be 9.36 MGD. Import water consists of water from sources such as free flowing streams and impoundments. The import requirement was lass than the lowest import quantity used in a study conducted by TTU to evaluate water availability at potential Eastern oll shale processing facilities in Alabama, Indiana, Kentucky, Michigan, Ohio, and Tennessee. Therefore, TTU directed the invstigation toward determining water quality characteris. tics at the sites selected in the study that can serve a $50,000 \mathrm{bbl} /$ day $\mathrm{PFH}$ processing facility. Water quality was investigated for each state to ensure an adequate representation of water quality.

Rivers are the primary source of water for 50,000 bbl/day processing facilities will be rivers, those considered are listed in Table 6-3 along with the states in which they serve as potential water sources.

Table 6-3. IMPORT WATER SOURCES INVESTIGATED

\begin{tabular}{l}
\multicolumn{1}{c}{ State } \\
\hline Alabama \\
Kentucky \\
Ohio \\
Indiana \\
Michigan \\
Tennessee
\end{tabular}

$\frac{1}{1}$ River
Tennessee
Ohio
Scioto
Ohio
Thunder Bay
Cumberland

The resu'ts of chemical and physical analyses conducted on samples from the selected rivers have been published previous $1 y^{6,7,8,9}$ and are summarized in Table 6-4. The Scioto River in Ohio clearly has the most undesirable water quality characteristics. Therefore, the use of these water quality characteristics as cesign parameters for treatment recommendations of import water will be the most conservative approach.

Confirmed Boiler Feedwater Criteria: The Electric Power Research Institute (EPRI) has established definitive guidelines for fossil fuel plant makeup water purity. ${ }^{10}$ These guidelines are as close to ari industry standard on boiler feedwater criteria as is available. The values for treated makeup are specific to the type of boiler used, whether or not a reheater is present, and the form of chemical treatment used within the boiler. Due to the lack of 
Table 6-4. CHARACTERISTICS OF IMPORT HATER SOURCES

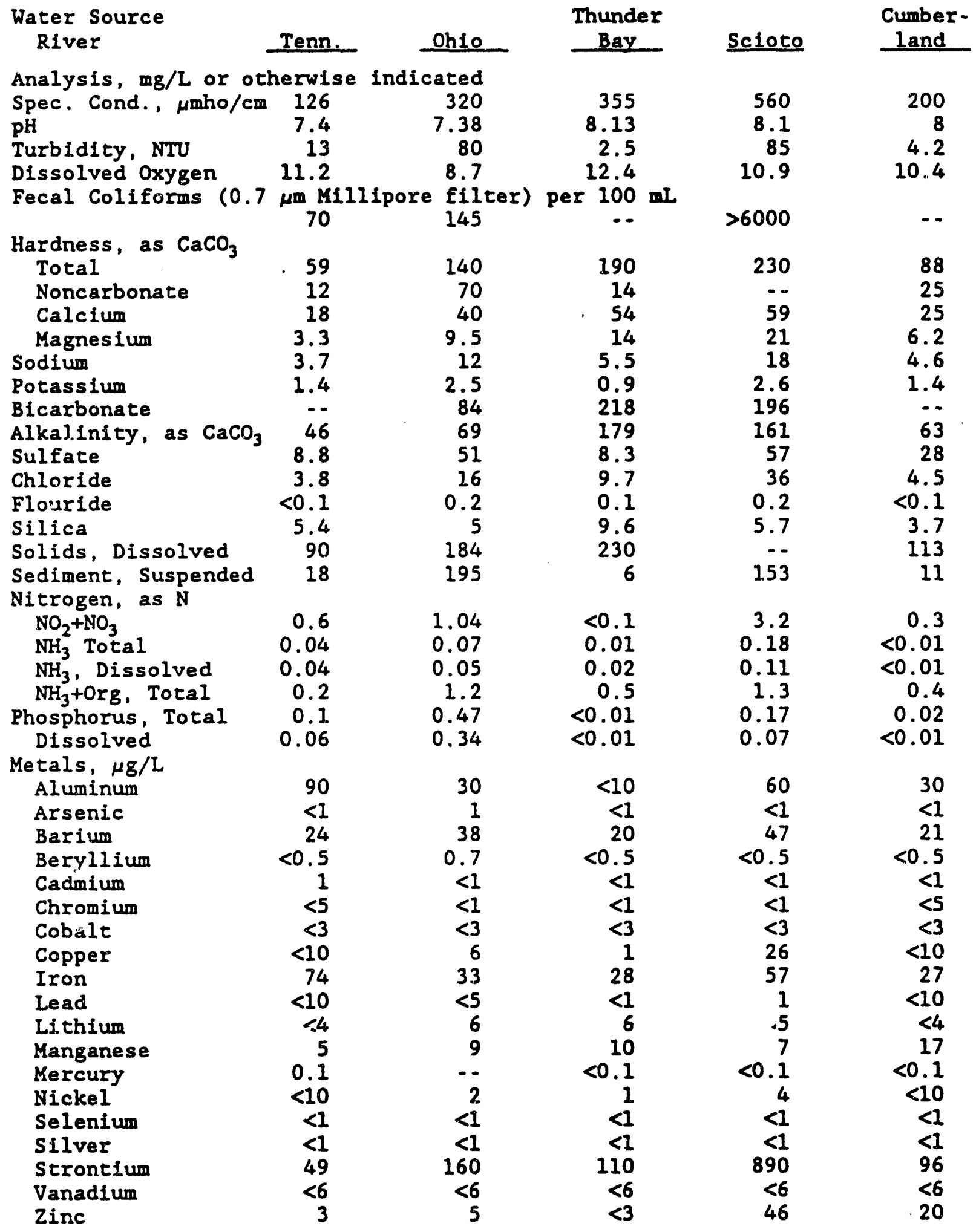


specifications for the boiler that will be used in the combined PFH-power plant, the conservative approach is to utilize the most stringent requirements of a high-pressure drum-type boiler that contains a reheater and utilizes all volatile treatment. A summary of the feedwater quality criteria for a boiler under these conditions is presented in Table 6-5. The values isted are the same as those for steam within the boiler unit. This was done to provide maximum flexibility and allows attainment of the desired steam purity.

Table 6-5. BOILER FEEDWATER QUALITY CRITERIA

\begin{tabular}{lc} 
Parameter & Maximum Concentration \\
\cline { 2 - 2 } Sodium, mg/L & 0.003 \\
Chloride, mg/L & 0.003 \\
Sulfate, mg/L & 0.003 \\
Silica, mg/L & 0.010 \\
Specific Conductivity & \\
e $25^{\circ} \mathrm{C}, \mu$ mho/cm & 0.1 \\
Total Organic Carbon, mg/L & 0.300
\end{tabular}

Subtask 6.4.1. PFH Process Analyses

The objective of this subtask is to analyze the data obtained from Task 3 and develop correlations describing the processes being developed as data become available.

\section{Discussion}

Due to the reduction in work scope, this task will not be Initiated.

\section{Subtask 6.4.4. Economics}

The objective of this subtask is to determine the cost to produce oil from beneficiated Eastern shale by evaluating the effects of operating conditions in the PFH retort, including the methane/hydrocarbon gas cracking and cracked-carbon combustion processing steps.

\section{Discussion}

Due to the reduction in work scope, this task will not be initiated.

Task 8. Profect Management and Reporting

The objective of this task is to coordinate all aspects of the program among DOE, IGT, and the various subcontractors to insure that a cohesive program is maintained.

IGT continued to review and monitor the progress of the subcontractors via telephone and written reports. In October, DOE notified IGT that funds were not available to fully fund work on Contract DE-AC21-87MC11089, "Pressurized Fluidized-Bed Hydroretorting of Eastern 0il Shale." DOE requested a 
revised statement of work to reduce the effort to correspond to the amount of money available while continuing the research at a reduced effort. IGT prepared a revised statement of work and a cost proposal for the revised statement of work with input from its subcontractors. A meeting was held at IGT in November to discuss the reduction in program work scope with DOE.

IGT and its subcontractors presented eight papers discussing the results obtained on the PFH program at the 1992 Eastern O11 Shale Symposium held in Lexington, Kentucky on November 17-20, 1992.

\section{Task 9. Information Required for the NEPA}

The requirements of the National Environmental Policy Act (NEPA) are defined by statute. The objective of this task is to provide information to DOE relevant to the potential environmental impacts of the program tasks so that DOE can determine if an environmental assessment or environmental impact statement is required.

\section{Discussion}

This task was inactive during the quarter, pending approval of the NEPA document submitted previously (August 1992) to DOE. The NEPA document contains input from IGT as well as each of the subcontractors participating in the program.

\section{FUTURE PLANS}

Work on the scheduled tasks will continue as outlined in the revised statement of work.

\section{ACKNOWLEDGMENTS}

IGT acknowledges the significant work being conducted on this project by the individual subcontractors, their principal investigators, and colleagues -

MRI: Dr. C. W. Schultz

UA: Professor W. E. Hatcher

UK-CAER: Dr. B. K. Parekh

TTU: Professor W. P. Bonner 
1. Johnson, L. R., and R. H. Ri:ey, "The Beneficlation of Eastern Oil Shales to Produce Oil Shale Concentrate for Retorting: An Engineering Study," Work performed for MRI under Grant No. DE-FG-21-85LC11066, Roberts and Schaeffer Company, December 1988.

2. Nalco Chemical Company, The NALCO Water Handbook, Second Edition, McGrawHill, Inc., 1979.

3. Process Chemistry for Water and Wastewater Treatment, Larry Benefield, Joseph Judkins, Jr., and Barron Weand, Prentice-Hall, Inc., Englewood Cliffs, New Jersey, 1982.

4. Wilkes, J.F. "Industrial Problems: Cooling Water and Cooling-Water Treatment." Corrosion Chemistry Vol. 89, ACS Symposium Serles, American Chemical Society, Washington, D.C., 1979.

5. Institute of Gas Technology, "Pressurized Fluidized-Bed Hydroretorting of Eastern Oil Shales," DE-AC21-87MC11089, Volume IV, Final Repori for the Period September 1987-May 1991.

6. U.S. Geological Survey, "U.S. Geological Survey Water-Data Report TN-90-1," 1990.

7. U.S. Geological Survey, "U.S. Geological Survey Water-Data Report $\mathrm{KY}-88-1$, " 1988 .

8. U.S. Geological Survey, "U.S. Geological Survey Water-Data Report OH-91-1," 1991 .

9. U.S. Geological Survey, "U.S. Geological Survey Water-Data Report MI-91-1, " 1991.

10. Electric Power Research Institute, Interim Consensus Guidelines on Fossil Plant Water Chemistry. EPRI CS-4629, Palo Alto, California, June 1986.

$61100 \mathrm{q} 5 /$ wp 5.1 

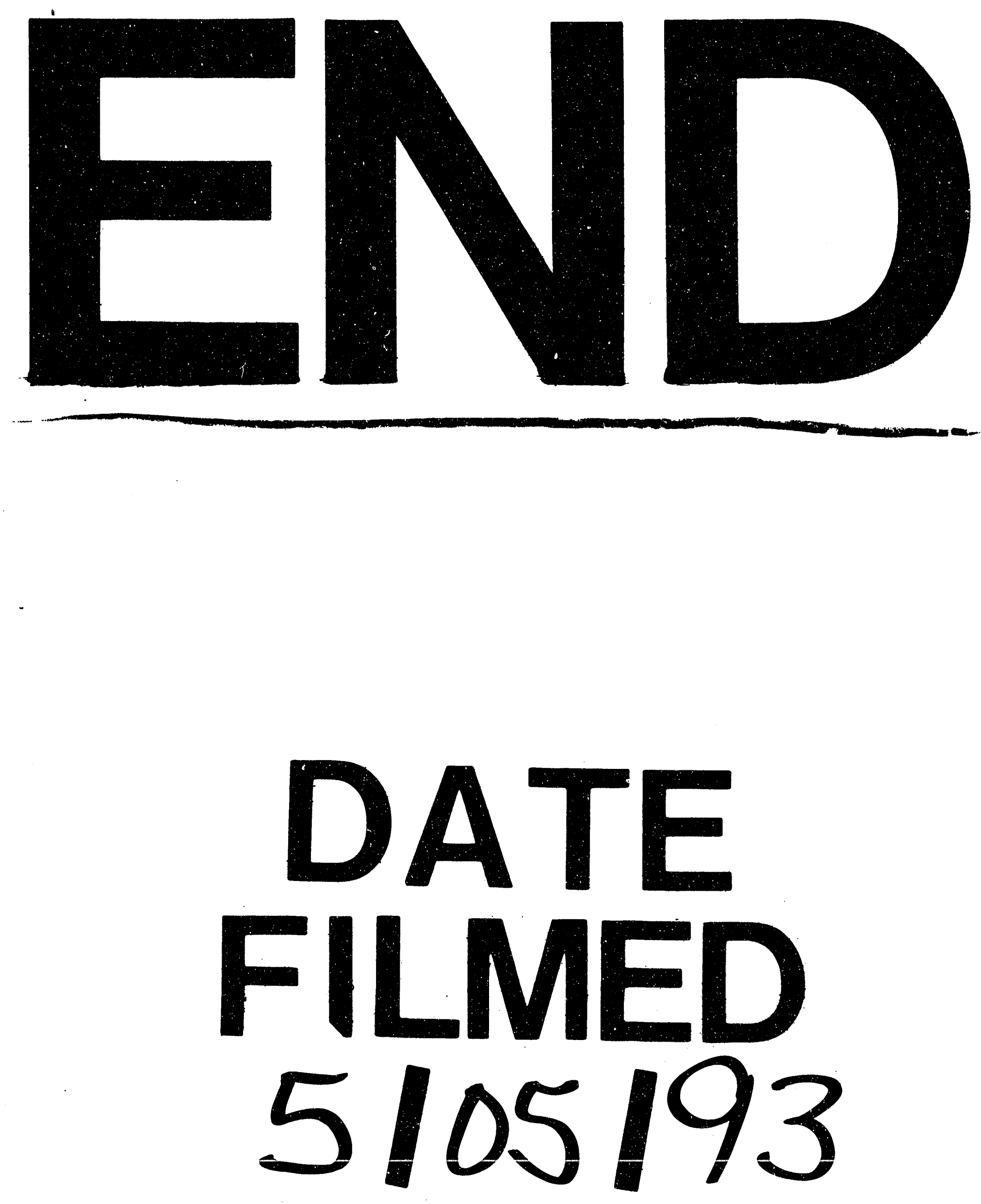
